\title{
Observations of the temporal variability in aerosol properties and their relationships to meteorology in the summer monsoonal South China Sea/East Sea: the scale-dependent role of monsoonal flows, the Madden-Julian Oscillation, tropical cyclones, squall lines and cold pools
}

\author{
J. S. Reid ${ }^{1}$, N. D. Lagrosas ${ }^{2}$, H. H. Jonsson ${ }^{3}$, E. A. Reid ${ }^{1}$, W. R. Sessions ${ }^{4}$, J. B. Simpas ${ }^{2}$, S. N. Uy ${ }^{2}$, T. J. Boyd ${ }^{5}$,

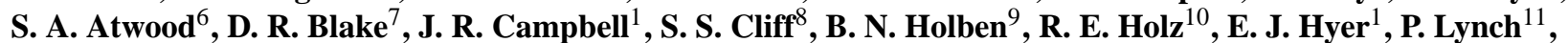 \\ S. Meinardi ${ }^{7}$, D. J. Posselt ${ }^{12}$, K. A. Richardson ${ }^{1}$, S. V. Salinas ${ }^{13}$, A. Smirnov ${ }^{14}$, Q. Wang ${ }^{3}$, L. Yu ${ }^{15}$, and J. Zhang ${ }^{16}$ \\ ${ }^{1}$ Marine Meteorology Division, Naval Research Laboratory, Monterey, CA, USA \\ ${ }^{2}$ Manila Observatory, Ateneo de Manila University campus, Quezon City, Philippines \\ ${ }^{3}$ Department of Meteorology, Naval Postgraduate School, Monterey, CA, USA \\ ${ }^{4}$ CSC, Naval Research Laboratory, Monterey, CA, USA \\ ${ }^{5}$ Biogeochemistry Section, Naval Research Laboratory, Washington, DC, USA \\ ${ }^{6}$ Dept. of Atmospheric Science, Colorado State University, Ft. Collins, CO, USA \\ ${ }^{7}$ Department of Chemistry, University of California, Irvine, CA, USA \\ ${ }^{8}$ Department of Applied Science, University of California, Davis, CA, USA \\ ${ }^{9}$ NASA Goddard Space Flight Center, Biospheric Sciences Laboratory, Code 618, MD, USA \\ ${ }^{10}$ Space Sciences Engineering Center, University of Wisconsin, Madison, WI, USA \\ ${ }^{11}$ CSC Inc. at Naval Research Laboratory, Monterey, CA, USA \\ ${ }^{12}$ Dept. of Atmospheric, Oceanic, and Space Sciences, University of Michigan, Ann Arbor, MI, USA \\ ${ }^{13}$ Centre for Remote Imaging Sensing and Processing, National University of Singapore, Singapore \\ ${ }^{14}$ Science Systems and Applications, Inc., Lanham, MD, USA \\ ${ }^{15}$ Dept. of Civil and \& Environmental Engineering, National University of Singapore, Singapore \\ ${ }^{16}$ Dept. of Meteorology, University of North Dakota, Grand Forks, ND, USA
}

Correspondence to: J. S. Reid (jeffrey.reid@nrlmry.navy.mil)

Received: 19 July 2014 - Published in Atmos. Chem. Phys. Discuss.: 8 August 2014

Revised: 17 January 2015 - Accepted: 21 January 2015 - Published: 19 February 2015

\begin{abstract}
In a joint NRL/Manila Observatory mission, as part of the Seven SouthEast Asian Studies program (7SEAS), a 2-week, late September 2011 research cruise in the northern Palawan archipelago was undertaken to observe the nature of southwest monsoonal aerosol particles in the South China Sea/East Sea (SCS/ES) and Sulu Sea region. Previous analyses suggested this region as a receptor for biomass burning from Borneo and Sumatra for boundary layer air entering the monsoonal trough. Anthropogenic pollution and biofuel emissions are also ubiquitous, as is heavy shipping traffic. Here, we provide an overview of the regional en-
\end{abstract}

vironment during the cruise, a time series of key aerosol and meteorological parameters, and their interrelationships. Overall, this cruise provides a narrative of the processes that control regional aerosol loadings and their possible feedbacks with clouds and precipitation. While 2011 was a moderate El Niño-Southern Oscillation (ENSO) La Niña year, higher burning activity and lower precipitation was more typical of neutral conditions. The large-scale aerosol environment was modulated by the Madden-Julian Oscillation (MJO) and its associated tropical cyclone (TC) activity in a manner consistent with the conceptual analysis performed 
by Reid et al. (2012). Advancement of the MJO from phase 3 to 6 with accompanying cyclogenesis during the cruise period strengthened flow patterns in the SCS/ES that modulated aerosol life cycle. TC inflow arms of significant convection sometimes span from Sumatra to Luzon, resulting in very low particle concentrations (minimum condensation nuclei $\mathrm{CN}<150 \mathrm{~cm}^{-3}$, non-sea-salt $\mathrm{PM}_{2.5}<1 \mu \mathrm{g} \mathrm{m}^{-3}$ ). However, elevated carbon monoxide levels were occasionally observed suggesting passage of polluted air masses whose aerosol particles had been rained out. Conversely, two drier periods occurred with higher aerosol particle concentrations originating from Borneo and Southern Sumatra $\left(\mathrm{CN}>3000 \mathrm{~cm}^{-3}\right.$ and non-sea-salt $\mathrm{PM}_{2.5} 10-25 \mu \mathrm{g} \mathrm{m}^{-3}$ ). These cases corresponded with two different mechanisms of convection suppression: lower free-tropospheric dry-air intrusion from the Indian Ocean, and large-scale TC-induced subsidence. Veering vertical wind shear also resulted in aerosol transport into this region being mainly in the marine boundary layer (MBL), although lower free troposphere transport was possible on the western sides of Sumatra and Borneo. At the hourly time scale, particle concentrations were observed to be modulated by integer factors through convection and associated cold pools. Geostationary satellite observations suggest that convection often takes the form of squall lines, which are bowed up to $500 \mathrm{~km}$ across the monsoonal flow and $50 \mathrm{~km}$ wide. These squall lines, initiated by cold pools from large thunderstorms and likely sustained by a veering vertical wind shear and aforementioned mid-troposphere dry layers, propagated over $1500 \mathrm{~km}$ across the entirety of the SCS/ES, effectively cutting large swaths of MBL aerosol particles out of the region. Our conclusion is that while largescale flow patterns are very important in modulating convection, and hence in allowing long-range transport of smoke and pollution, more short-lived phenomena can modulate cloud condensation nuclei $(\mathrm{CCN})$ concentrations in the region, resulting in pockets of clean and polluted MBL air. This will no doubt complicate large scale comparisons of aerosolcloud interaction.

\section{Introduction}

Given its hypothesized sensitivity to global climate change (e.g., IPCC, 2007; Yusuf and Francisco, 2009), Southeast Asia (SEA) has experienced a substantial increase in scientific interest; from the region's highly complex meteorology, to its atmospheric chemistry, air quality, and climate. The region, including the maritime continent, South China Sea/East Sea (SCS/ES), and Sulu Sea, is thought to be highly susceptible to aerosol cloud interactions (Rosenfeld, 1999; Hamid et al., 2001; Yuan et al., 2011). Indeed, around the second half of the boreal summer monsoonal period from August to mid-October, the seasonal dry climate allows biomass burning throughout the maritime continent (MC), particularly in warm El Niño-Southern Oscillation phases (e.g, Nichol, 1998; van der Werf et al., 2004; Field and Shen, 2008; Langner and Siegert, 2009; Field et al., 2009; van der Kaars et al., 2010; Reid et al., 2012, 2013). Climatologically, there exists both anecdotal evidence and some station data suggesting an increase in the number of no-rain days in the Philippines (Cruz et al., 2013), yet perhaps an increase in intense events (Cinco et al., 2014). Perhaps such a behavior is a result of the effect of increasing aerosol emissions on clouds. At the same time there is a long-standing hypothesis that there are increases in mid-level cloudiness, also perhaps due to increased levels of aerosol particles (Parungo et al., 1994).

Under most circumstances, smoke and pollution from the $\mathrm{MC}$ is thought to be transported by southwesterly monsoonal winds into the SCS/ES where it is scavenged by convection with eventual annihilation in the monsoonal trough (Reid et al., 2012; Xian et al., 2013). However, the transition process between "polluted land" and "clean monsoonal trough" is poorly understood. Large scale modeling studies suggesting smooth transport are at odds with visible imagery (Reid et al., 2013) and lidar observations (e.g., Campbell et al., 2013), which suggest smoke is often sequestered on or very near the major land masses. Owing to near ubiquitous high cloud cover in the SCS/ES, there are relatively few satellite observations of smoke transport in the region, except during anomalously clear or severe events. The limited remote sensing data that are available is largely qualitative, with both cloud and aerosol retrievals showing great regional diversity across product lines in this near-ubiquitous cloud environment (Reid et al., 2013). While higher-frequency meteorological phenomena, such as the Madden-Julian Oscillation and equatorial waves (Reid et al., 2012), as well as orographic and sea breeze effects, are thought to exert significant influence on transport (Mahmud, 2009a, b; Reid et al., 2012; Wang et al., 2013; Xian et al., 2013), there are virtually no in situ observations of the SCS/ES aerosol environment in this critical summer monsoonal season. Cloud processes in regions such as the $\mathrm{MC}$ are expected to be sensitive to the presence of aerosol particles (e.g., Sorooshion et al., 2009; Yuan et al., 2011; Lee et al., 2012). But, we have little information on how well models perform.

As part of the Seven Southeast Asian Studies (7-SEAS) program (Reid et al., 2013), a 2-week research cruise was conducted from 17 to 30 September 2011 in the northern half of the Palawan archipelago of the Philippines; a region thought to be a long-range receptor for MC biomass burning and industrial emissions (Reid et al., 2012; Xian et al., 2013). At the same time, additional sun photometer, lidar and ground measurements were made in Singapore to contrast with the Philippine receptor. Other sun photometers were located across Southeast Asia. Conducted on the M/Y Vasco, a locally owned $35 \mathrm{~m}$ vessel, our goals were to make first-ever (to our knowledge) measurements of near-surface aerosol properties in the region, test the transport hypotheses put forth in Reid et al. (2012), and develop new hypotheses on 
aerosol-weather interaction that regulate aerosol prevalence to be studied in future deployments. Most importantly, we aim to develop a narrative on how model simulations and remote sensing retrievals correspond with real world observations in this highly complex aerosol and meteorological environment. Often, the intricacies of aerosol-meteorological relationships are blurred in bulk analyses to the detriment of understanding regional physics and chemistry. Only through studies, such as the one presented here, can we hope to derive the true sensitivity of the region to aerosol emissions.

In this paper, we give a brief overview of the cruise and its measurements, as well as other regional measurements made to aid in interpreting the regional aerosol environment. This will form a descriptive basis for subsequent 7-SEAS papers on aerosol and cloud features for the 2011 burning season, as well as a contrast to a similar 2012 cruise to be reported at a later date. The analysis portion of this paper is focused on the temporal variability of aerosol particle number and mass concentrations and how these relate to regional meteorological phenomenon, such as large scale monsoonal flow, the Madden-Julian Oscillation (MJO), tropical cyclone (TC) development and propagation, and large scale squall lines/cold pools. We end with a discussion of the strong covariance between aerosol prevalence and regional thermodynamic behavior, noting how it must be considered in studies of aerosol, cloud, and precipitation interaction.

\section{Cruise description and instrumentation}

This research cruise was conducted on the $35 \mathrm{~m}, 186$ ton M/Y Vasco, owned and operated by Cosmix Underwater Research Ltd. Manila, Philippines. Photos of the vessel along with its cruise track are provided in Fig. 1. The Vasco departed on 17 September 2011 from Navotas, Manila Bay, and returned midday 30 September. The target area for the bulk of the monitoring was in the vicinity of El Nido and outside of Malampaya Sound, Palawan Island $\left(\mathrm{Lat}=111.1^{\circ} \mathrm{N}\right.$; Long $=119.3^{\circ} \mathrm{E}$ ). The general mode of operation was to travel to selected areas, then choose locations for sampling which had a clear breeze to the open ocean, though protected from the sometimes large swell with no local wave breaking. Great care was taken to not position the ship downwind of any sources. Indeed, small settlements are ubiquitous on small islands. But these were all avoided. The ship would move every 1-2 days within each area to support other physical oceanographic measurements. The route south from Manila included a 1-day stop at Apo Reef on 18 September, and the coast of Culion on 19 September. From 20 September through the morning of 28 September the Vasco operated in the northern Palawan area. On the morning of 29 September, the Vasco departed El Nido for return to Manila on the early afternoon of 30 September.

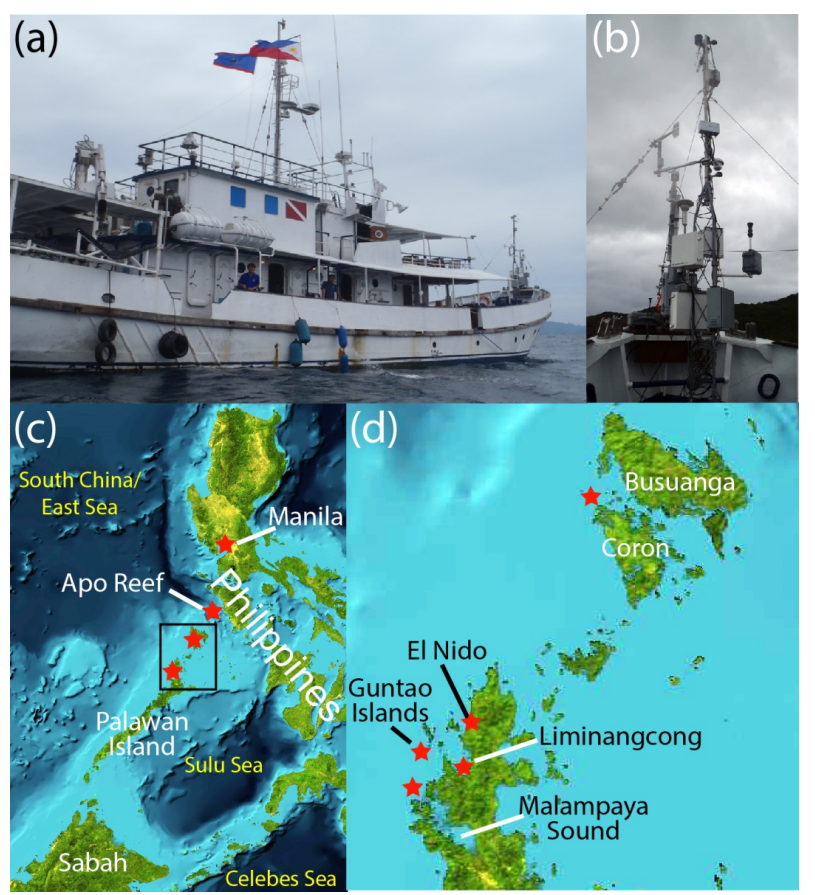

Figure 1. (a) The M/Y Vasco; (b) bow flux tower during the cruise. (c) Map of cruise area, stars mark key areas of sampling. (d) Enlargement of the northern Palawan/Coron sampling sites.

Instrumentation was generally deployed in two configuration groups. Self-contained instrumentation, including meteorology and aerosol chemistry, was located on a $3 \mathrm{~m}$ flux tower on the bow of the ship, a total top-to-bottom height of $6 \mathrm{~m}$ above the ocean surface. This ensured no selfcontamination from the ship except for very rare periods of a following wind. Aerosol particle counters and nephelometers were located in a forward locker fed by a $4 \mathrm{~cm}$ diameter $/ 4 \mathrm{~m}$ long inlet from the top of the ship. Wind directional data ensured that only periods with air moving over the bow were used (to remove periods of contamination and self-sampling from the data set). Periods of self-sampling were also abundantly clear from CN (Condensation Nuclei) counts. Such periods were obvious, with rapid particle count fluctuations in the 1000 to $10000+$.

\subsection{Meteorology}

The meteorological instrumentation set was associated with the $3 \mathrm{~m}$ flux tower. While fluxes are a subject of a separate paper, a brief summary is appropriate here. A Campbell sonic anemometer and LI-COR IR $\mathrm{H}_{2} \mathrm{O} / \mathrm{CO}_{2}$ system were sampled at $50 \mathrm{hz}$ to provide fluxes of momentum, sensible and latent heat. Mean meteorology was also provided by an R.M. Young propeller anemometer and a Campbell pressure and ventilated temperature and humidity probe. Sea surface temperature was provided by a waterline floating thermocouple. Downwelling shortwave radiation was measured with a Kipp 
and Zonen CMP 22 radiometer. Ship location and attitude were given by a Garmin GPS and accelerometer package. This attitude and velocity data was used to correct meteorology and solar radiation data.

In addition to the flux tower, ceiling and visibility were provided by a Vaisala $\mathrm{C} 31$ ceilometer, which has been shown to provide information on aerosol particle profiles when properly corrected (e.g., Clarke et al., 2003; Markowicz et al., 2008; Tsaknakis et al., 2011). Twenty-five InterMet 1$\mathrm{AB}$ radiosondes were also released during the cruise, generally one to two per day; 20 of these passed our quality control. Forward-looking automatic cameras logged images every minute.

\subsection{Aerosol and gas chemistry}

A series of aerosol samplers were mounted on the bow of the ship. One of the primary instruments utilized in this paper was a free-standing eight-stage Davis Rotating-drum Uniform size-cut Monitor (DRUM) sampler. The instrument used in this study was a version of the DRUM sampler originally described by Cahill et al. (1985), modified to utilize slit orifices and configured to run at $16 \mathrm{~L} \mathrm{~min}^{-1}$ as described in Reid et al. (2008). A similar instrument was deployed for comparison to Dongsha Island in the SCS/ES in 2011 in the winter/spring northeasterly monsoon (Atwood et al., 2013a). An unheated $\mathrm{PM}_{10}$ sample inlet was used upstream of the impactor, followed by collection stages with nominal $50 \%$ aerodynamic diameter-cut sizes of 5, 2.5, 1.15, 0.75, 0.56, $0.34,0.26$, and $0.07 \mu \mathrm{m}$. Aerosol particles were collected on Mylar strips coated with Apiezon grease and wrapped around each rotating drum. The drums were rotated at a consistent rate such that nominal timestamps could be assigned to specific locations along the strip during compositional analyses, yielding $90 \mathrm{~min}$ time resolution. DRUM samples were subjected to X-ray fluorescence (XRF) analysis at the Advanced Light Source (ALS) of Lawrence Berkeley National Laboratory to provide measurements of selected elements having atomic weights between $\mathrm{Mg}$ and $\mathrm{Mo}$, along with $\mathrm{Pb}$. Unlike previous DRUM analyses described in the literature, the XRF analysis samples for this study utilized a more advanced detector system, making XRF derivations of key sea salt elements, such as $\mathrm{Na}$ and $\mathrm{Cl}$ much more quantitative. For simplicity here, time series of elemental concentration data for the eight raw-size fractions were combined into two lumpedsize fractions: coarse (stages $1-3$ or $10-1.15 \mu \mathrm{m}$ in aerodynamic size), and fine (stages 4-8, or 1.15-0.07 $\mu \mathrm{m}$ ), respectively. A more detailed analysis will be provided by a forthcoming paper.

$\mathrm{PM}_{2.5}$ filters were also collected in daily $5 \mathrm{~L} \mathrm{~min}^{-1}$ MiniVol Tactical Air Samplers (TASs) and analyzed by gravimetric, XRF and ion chromatography at the Desert Research Institute. A second set of filters provided organic and black carbon by the method of Chow et al. (1993). Finally, $\mathrm{PM}_{10}$ and 2.5 samples were collected by the Manila Obser- vatory using both TASs and a three-stage Dylec impactor for gravimetric and ion chromatography analysis. These, too, are discussed in Lagrosas et al. (2015).

For trace-gas analysis, 46 whole-air gas samples were collected in electro-polished stainless steel cans for analysis by gas chromatography by the University of California Irvine. See Colman et al. (2001) for details, a full list of $60+$ compounds, and relative uncertainties. However, only a few species are presented here (e.g., CO, and few halo and hydrocarbons). Flame ionization detectors (FIDs) were used to measure $\mathrm{C}_{2}-\mathrm{C}_{10}$ hydrocarbons, electron capture detectors (ECDs) were used for $\mathrm{C}_{1}-\mathrm{C}_{2}$ halocarbons and $\mathrm{C}_{1}-\mathrm{C}_{5}$ alkyl nitrates, and quadrupole mass spectrometer detectors (MSDs) were used for unambiguous compound identification and selected ion monitoring. Cans were supplied for the cruise under vacuum, and upon valve release at the ship's bow under headwind, each collected its volume over the course of $\sim 20 \mathrm{~s}$. Measurement precision varied by species, but was better than $5 \%$ for the vast majority of species. The most uncertain was dibromochloromethane at $8 \%$. Cans were opened sporadically throughout the cruise, with at least two samples a day being collected, generally in the morning and afternoon. Sampling was generally not performed during rain showers. Additional cans were sampled during excellent or interesting sampling conditions, with the highest frequency during the last few days when the ship was a receptor for smoke. Of the 46 can samples, 5 did not pass quality assurance as they had anomalously high hydrocarbon and solvent levels. Given the collection procedure, based over the side on the windward bow of the ship, we are not entirely sure how the contamination may have happened, but suspect it may reflect some local contaminant from the scattered islands in the region. For the purposes of this paper on large scale flow, they are excluded here.

\subsection{Ship aerosol microphysics and optics}

Onboard the Vasco were a particle counter, sizers, and a nephelometer. Total particle concentrations were measured by a TSI water condensation nuclei counter (CPC, http://www.tsi.com/ water-based-condensation-particle-counter-3785/). Fineand coarse-mode particle size was provided by a DMT (Droplet Measurement Technologies) bench-top Passive Cavity Aerosol Sizing Spectrometer (PCASP), and a TSI Aerodynamic Particle Sizer (APS) which were calibrated before and after the cruise. These low-flow rate instruments were behind a Dry-Rite drying column, which dropped relative humidity to $\sim 50 \%$. However, while the CPC and APS operated without incident, the PCASP suffered a relay failure after the first night at sea (night of 17 September). This was repaired by 24 September for the second half of the cruise.

For light scattering, we used a TSI three-wavelength nephelometer $(\lambda=445,550,700 \mathrm{~nm})$ at ambient $\mathrm{RH}$, and 
corrected for truncation/non-Lambertian light source errors using Anderson et al. (1996). A three-wavelength particle soot absorption photometer (PSAP) sampled from the nephelometer stream, and was corrected via Bond et al. (1999). A Radiance Research single-wavelength nephelometer $(\lambda=532)$ was also placed downstream of the drying column. Finally, a Microtops hand-held sun photometer was brought on board as part of the Maritime Aerosol Network (MAN; Smirnov et al., 2011) for measuring aerosol optical thickness (AOT). However, cloudy skies prohibited measurements prior to the last two days of the cruise (29 and 30 September). Comprehensive studies of aerosol optical properties and size are a subject of a subsequent paper. However, here we use the CPC and PCASP to show the time series of basic fine-mode particle number and size properties.

\subsection{Regional AERONET measurements}

In addition to the Vasco cruise, a number of other instruments were placed in the region to help monitor the aerosol environment. Most notable, in reference to this paper, was a set of four AERONET sun photometers (Holben et al., 1998), located on the map in Fig. 2b. Two sites including the Singapore 7-SEAS super site (e.g., Atwood et al., 2013b), Kuching, Sarawat Borneo (Salinas et al., 2013) and Marbel University, Mindanao, Philippines were set up for 7SEAS. Songkhla, Thailand was pre-existing operational. For the purposes of this paper, we focus one parameter, $500 \mathrm{~nm}$ daily averaged fine-mode AOT. This was generated from the Level 2.0 spectral deconvolution algorithm (SDA) version 4.1, used to separate fine- and coarse-mode contributions to AOT (O'Neill et al., 2003). By using the SDA, we can effectively remove thin cirrus contamination (Chew et al., 2011) and focus on fine-mode particles from industrial and biomass burning sources.

\subsection{Ancillary satellite and model data}

Baseline meteorology data are provided by the Navy Global Atmospheric Prediction System (NOGAPS; Hogan and Rosmond, 1991). We compared NOGAPS fields to NCAR reanalysis fields (Kalnay et al., 1996) for the individual events discussed in this paper and, as we found no substantive differences. NOGAPS data are subsequently used for initializing the offline Navy Aerosol Analysis and Prediction System (NAAPS). NAAPS, the Navy's operational aerosol model, is a global operational $1^{\circ} \times 1^{\circ}$ aerosol transport model supporting various operations and research, including the monitoring of biomass burning plumes (Reid et al., 2009). NAAPS has been extensively exercised for the maritime continent region (e.g., Hyer and Chew, 2010; Reid et al., 2012; Xian et al, 2013). The emissions, transport, and sinks of a combined pollution product (particulate organic matter plus sulfates), open biomass burning smoke, and dust are simulated, and quality-assured AOT retrievals from MODIS observations
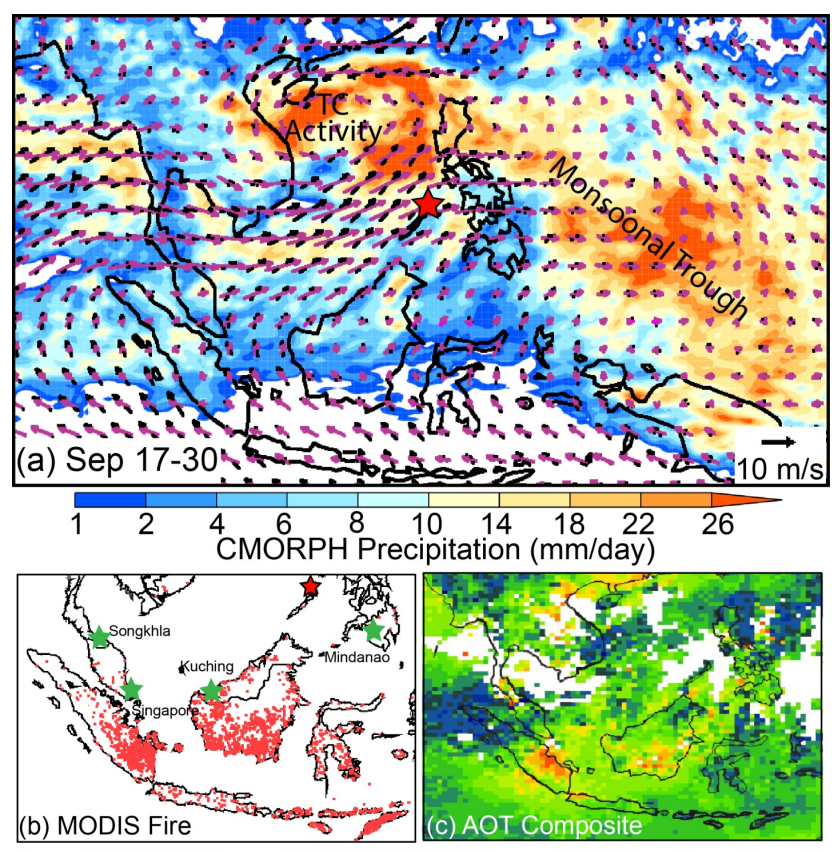

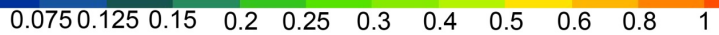
MISR, MODIS Composite Average AOT (550 nm)

Figure 2. Overview of the aerosol and meteorological environment during the 17-30 September Vasco cruise. (a) Surface (black) and $850 \mathrm{hPa}$ (purple) NOGAPS winds overlaid on CMORPH average precipitation rain rates. (b) MODIS Terra+Aqua active fire hotspot detections during the cruise. Overlaid in green stars are key AERONET locations. Red star depicts the El Nido receptor site sampled by the Vasco. (c) Composite average MODIS+MISR aerosol optical thickness (AOT).

are assimilated into the model (Zhang et al., 2008). Model output includes predicted speciated mass concentrations and AOT. The NAAPS data were used to provide a regional assessment, as well as along the ship track.

To establish mid- and upper-troposphere air-mass source regions, and the large scale flow pattern for selected periods of the cruise, back trajectories were generated using the NOAA Hybrid Single Particle Lagrangian Integrated Trajectory (HYSPLIT) Version 4.9 Model (Draxler and Hess, 1997, 1998; Draxler, 2004). The GDAS1, $1^{\circ} \times 1^{\circ}$ global meteorological data set, generated for HYSPLIT from the Global Data Assimilation System model, was used to run $72 \mathrm{~h}$ backwards trajectories.

Numerous satellite products (visible, IR, cloud heights, scatterometer, etc.) are also used in an imaging capacity to aid in the analyses. These can all be found on the NEXSAT system (Miller et al., 2006; http://www.nrlmry. navy.mil/nexsat-bin/nexsat.cgi) and are cited as used in this paper. We also use other retrieved products for context, such as the Climate Prediction Center (CPC) MORPHing technique (CMORPH, Joyce et al., 2004) for precipitation and derived data assimilation-grade satellite AOT products from 
MODIS (Zhang et al., 2008) and MISR (Kahn et al., 2009). MODIS fire counts are also used here, following the regional interpretation of Hyer et al. (2013). While it would have been highly valuable, Cloud-Aerosol Lidar and Infrared Pathfinder Satellite Observations (CALIPSO) data were not collected during the cruise period due to solar anomalies. However, we do present a single collection from 1 October in conditions we believe to be representative of the last few days of the cruise.

\section{Results I: regional meteorological and aerosol characteristics}

The Vasco cruise occurred in the second half of the month of September 2011. This period is typically towards the end of the boreal summer southwest monsoon (henceforth SWM) system, approximately 2-3 weeks before the transition period to the boreal winter/spring northeast monsoon (NEM). A general overview of the summer monsoonal system can be found in Chang et al. (2005), Moron et al. (2009) and the book by Chang et al. (2011). An overview of how monsoonal weather features relate to smoke emissions and transport from progressively larger to finer scales can be found in Reid et al. (2012), Xian et al. (2013), Mahmud (2009a, b) and Wang et al. (2013), respectively. A brief description of key meteorological and aerosol elements for the summer 2011 burning season, as they relate to the study measurement period, is provided here.

\subsection{Overall nature of the meteorological and aerosol environment}

As discussed in the references above, the SWM in the greater Southeast Asian region is generally between mid-April and mid-October. Associated lower-atmospheric flows in the MC are easterly when south of $3^{\circ} \mathrm{S}$, and westerly when north of this latitude. In the SCS/ES, surface winds turn southwesterly, eventually terminating in a monsoonal trough east of the Philippines. In the upper free troposphere over the SCS/ES, winds flow in the opposite direction to the marine boundary layer and lower free troposphere: generally northeasterly, originating from the monsoonal trough. The $\sim 500 \mathrm{hPa}$ level generally is the delineation between southwest winds below and northeast winds above. Winds at these mid-levels are generally light.

For the purposes of this paper, the general meteorology during the cruise is depicted in Fig. 2a, where NOGAPS surface and $850 \mathrm{hPa}$ winds (black and magenta, respectively) are provided. These two levels bound the vast majority of aerosol particles in the region during the SWM (Tosca et al., 2011; Campbell et al., 2013; Chew et al., 2013; Wang et al., 2013). Average study period precipitation from CMORPH is also provided as the color background. The red star in the northern Palawan area indicates the Vasco's position during the bulk of the sampling. Figure $2 \mathrm{~b}$ provides a map of all MODIS (Terra+Aqua) fire counts during the study period. Here, green stars indicate relevant AERONET sun photometer data utilized in this study. Finally, Fig. 2c provides the average MODIS + MISR AOTs for the mission, although readers should be aware that AOTs in the northern half of the domain were derived from only the last few days of the study when skies were clear enough to perform a retrieval (this is discussed in more detail later).

The wind fields in the SCS/ES during the study period were largely typical for the SWM season, with its prevailing southwesterly winds, averaging $\sim 8-20 \mathrm{~m} \mathrm{~s}^{-1}$ over most of the region. The transition from easterlies and southeasterlies south of the Equator to southwesterlies in the SCS/ES can be seen in the general wrapping of the winds around Borneo and Sumatra. Wind strength anomalies were generally low over the region, although in the middle of the SCS/ES positive anomalies were on the order of $7 \mathrm{~m} \mathrm{~s}^{-1}$. Clear cyclonic activity in the northern SCS/ES region is also apparent. As we discuss later, these positive wind anomalies are result of TC activity and inflow arm wind enhancement during the cruise. Also notable is the slight veering wind shear at lowest levels. While the surface winds are clearly southwesterly, they do become more westerly through the lower free troposphere to $700 \mathrm{hPa}$. As discussed later, this has significant implications for regional aerosol transport and convection.

Precipitation is a maximum along the monsoonal trough, which extends from the northern SCS/ES to the southeast. However, during the mission, precipitation was not continuous in this region, but was rather a composite of enhanced local precipitation, lows, squall lines and tropical cyclone development. Secondary precipitation maxima were visible and include (1) convection over land; (2) precipitation west of Sumatra in the so called West Sumatran low, and (3) convection east of Myanmar driven by convergence of oceanic air masses reaching land. A depiction of the diversity of regional cloud features during the mission can be seen in Fig. 3. An area of near absence of precipitation south of southern Borneo and southern Sumatra except for isolated mountain top convection, encompassing such islands as Java and Timor, is a common feature of the SWM.

The 2011 season corresponded to a moderate La Niña year (Multivariate ENSO (El Niño-Southern Oscillation) In$\operatorname{dex}=-0.95)$. This typically implies higher precipitation and less fire activity than normal (Field and Shen, 2008; Field et al., 2009; Reid et al., 2012). However, in this particular year, precipitation and fire activity were more characteristic of a neutral year. Thus, while fire activity and smoke AOTs were not akin to the boreal summer El Niño events of 1997, 2004, 2006, and 2009, the year 2011 ranks in the middle third in our estimate of fire activity since 2000 (based on Reid et al., 2012, statistics). As is typical for the late SWM, fire activity was concentrated in southern Sumatra and southern Borneo/Kalimantan. Fires in this region are often associated with peatland burning, although a great deal of plantation and 
(a) Daily Mean Surface Wind and Precipitation

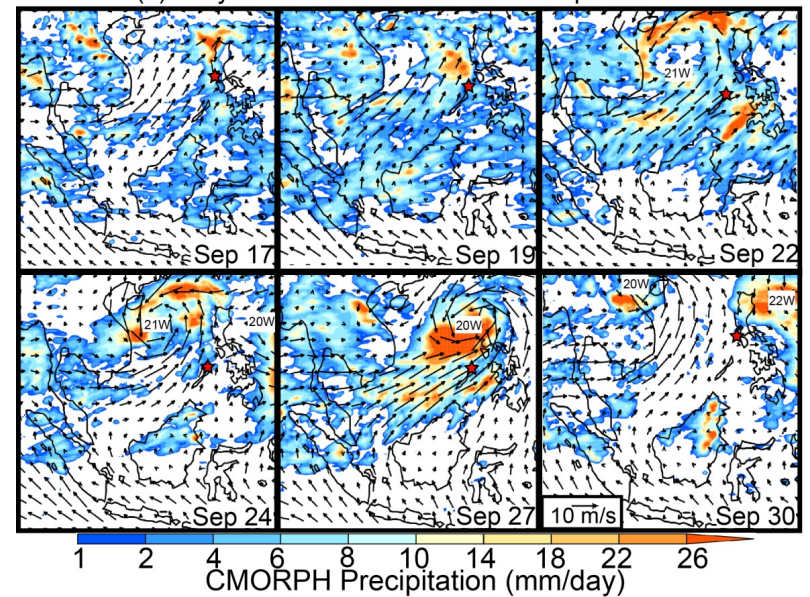

(b) MTSAT $330 Z$ Visible Imagry

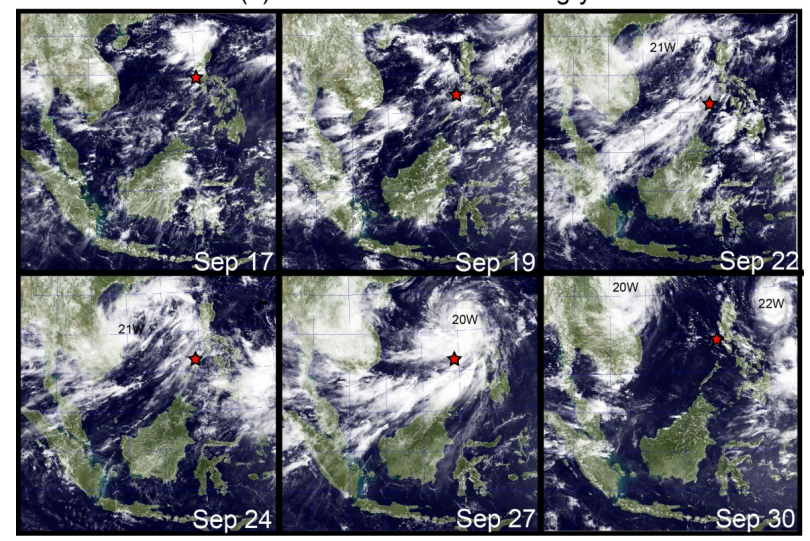

Figure 3. (a) Daily NOGAPS surface winds with CMORPH precipitation for 6 days throughout the cruise demonstrating key meteorological and aerosol modes. (b) Corresponding NexSat 03:30 UTC/11:30 LST MTSAT visible imagery with synthetic color background. Ship location at satellite imagery time is located by a red star.

small holder slash burning is common (see Reid et al., 2013 for a discussion of regional burning practices). As actual peat burning is much more common in drought years (e.g., Field and Shen, 2008; Miettinen et al., 2010, 2011), we suspect much of the observed burning was associated with agricultural maintenance or deforestation.

Intermediate fire activity corresponded with moderate AOT in the region, as can be seen in Fig. $2 \mathrm{c}$ that provides average composites of MISR and MODIS (Terra+Aqua) AOT. Near the biomass burning sources, AOTs can be high, averaging over 1 for $\lambda=550 \mathrm{~nm}$. This is likely low-biased, as AOT retrievals often flag thick aerosol plumes as cloud in the region (Reid et al., 2013). Comparison of the Fig. 2 panels elucidates regional transport patterns: smoke generated in Sumatra and Borneo is carried by the southwesterly winds through the SCS/ES and eventually scavenged out. Some Sumatran smoke also crosses the island's western mountain range and enters the Indian Ocean. While model represen- tation of regional smoke transport often suggests a smooth transition, imagery - and both passive satellite and lidar observations - often depict a strong gradient between island and ocean (e.g., Campbell et al., 2013; Reid et al., 2012, 2013). Prevailing hypotheses for this divergence surround scale-dependent issues in the model, and the reproducibility of orographic and sea breeze meteorology (e.g., Reid et al., 2012; Wang et al., 2013; Xian et al., 2013). But overall, the transport and transformation mechanisms from polluted island to clean marine background air are not well understood nor easily simulated. This paper, as well as subsequent efforts based on this cruise, hope to address these problems.

\subsection{Evolution of the meteorological environment during the Vasco cruise}

The timing of the Vasco cruise was serendipitous, as it coincided with the transition of the MJO from wetter to a drier phase in the MC. The MJO is a large-scale, coupled pattern of meso-synoptic scale circulation and deep convection that forms in the Indian Ocean and propagates eastward at $\sim 5 \mathrm{~m} \mathrm{~s}^{-1}$ through and around the MC and into the Pacific Ocean (Madden and Julian, 1971; Zhang, 2005, 2014). Phase and amplitude of the MJO are quantified for this study using the method of Wheeler and Hendson (2004). Once this convective region passes into the central/eastern Pacific and decays, a new event may start in the Indian Ocean, repeating the cycle. From an aerosol point of view, while ENSO is an excellent large-scale indicator of seasonal burning, the wet and dry phases of the MJO strongly influence the intraseasonal timing of significant smoke events in the MC (Reid et al., 2012). While the MJO was hypothesized to influence overall AOT (Tian et al., 2008), no satellite-based AOT verification of this has yet been established due to the difficulty in performing aerosol remote sensing in the region (Reid et al., 2013). However, fire observations are strongly enhanced in dry phases (Reid et al., 2012) and mechanistically a relationship between dry MJO phase, fire emissions, and high AOT seems certain.

An important correlation of MJO-related convection as it transits and departs the $\mathrm{MC}$ is an associated increase in the formation of regional TCs (Maloney and Hartman, 2001). Reid et al. (2012) noted that when TCs transit the SCS/ES there is an increase in both fire activity in the southern MC and ventilation of smoke into the SCS/ES region. This relationship is thought to be associated with an acceleration of southwesterly winds in the SCS/ES as air approaches the TC. As TCs enter the area, strong convection develops along the inflow arm, scavenging smoke transported offshore. Later, as the TC passes, large-scale subsidence follows, resulting in negative precipitation anomalies over much of the SCS/ES and the MC. An example of such a case is presented in global and mesoscale simulations in Reid et al. (2012) and Wang et al. (2013), respectively. Over the period of 17-30 September, the MJO convective active phase migrated out of the 
MC (that is migrated from Phase 3 to Phase 6) at a relative strength that increased above the 1 standard deviation intensity level halfway through the period. The migration of the MJO coincided with a train of TC activity beginning 23 September.

Select examples of daily mean winds with precipitation and representative daytime MTSAT visible images are found in Fig. 3a, b, respectively. On 17 September, the day of departure, the general meteorology of the SCS/ES and the MC was fairly typical for a convectively active phase of the MJO. Regional lower-tropospheric winds exhibited small anomalies against the NCEP (National Centers for Environmental Protection) climatology. Comparison of the CMORPH-derived precipitation (Fig. 3a) with MTSAT visible images (Fig. 3b) suggested the whole region was showery, with light, scattered precipitation from many small to medium-sized cells and a few deep and intense storms. Some organization can be seen, however, in an $800 \mathrm{~km}$ wide area in the SCS/ES between southern Vietnam and Borneo. Over the next $48 \mathrm{~h}$ (19 September), precipitation over the region increased, and the patch of convection in the SCS further organized and intensified. By 22 September, convection intensified further over the whole SCS/ES, and cyclonic rotation became clearly evident around a tropical depression in the northern SCS. This coupled system resulted in lines of convection and heavier precipitation from the southwest to the northeastern side of the SCS/ES. The tropical depression was later named Tropical Storm $21 \mathrm{~W}$-Haitang. Haitang continued developing until 25 September, reaching maximum winds of $18 \mathrm{~m} \mathrm{~s}^{-1}$. The inflow arm of Haitang moved westward, leaving the southern SCS/ES drier.

As Haitang was beginning to develop, a separate system, $20 \mathrm{~W}$ Nesat, rapidly intensified in the western Pacific Ocean and migrated westward. As Haitang then migrated into northern Vietnam, Nesat developed, making landfall on Luzon on 26 September with maximum 1 min sustained wind speeds of $\sim 58 \mathrm{~m} \mathrm{~s}^{-1}$ - ultimately listed as a Category 4 TC. After passing Luzon and causing an estimated USD 1 billion damage, Nesat lost strength to Category 1 before making landfall again at Hunan Island on 29 September. Finally, the third tropical cyclone, the westward-tracking Typhoon \#22W Nalgae made landfall in northern Luzon as a more compact but stronger Category 4 storm $\left(67 \mathrm{~m} \mathrm{~s}^{-1}\right.$ sustained) on 1 October. Detailed discussion of these storms can be found in the Joint Typhoon Warning Center Annual Tropical Cyclone Report (http://www.usno.navy.mil/NOOC/ nmfc-ph/RSS/jtwc/atcr/2011atcr.pdf).

These three tropical storms changed the nature of the regional meteorology for the second half of the cruise, and as we discuss, modulated regional aerosol loadings. Satellite imagery clearly showed the region oscillating between significant convection, developing in inflow arms (e.g., 22 and 27 September) across the SCS/ES, followed by areas of considerable clearing (e.g., 24-25 and 29-30 September). Inflow arms corresponded with increases in southwesterly winds, perhaps further ventilating MC air into the SCS/ES region.

\subsection{Evolution of the overall aerosol environment during the Vasco cruise period}

To provide context to regional fire and aerosol behavior during the Vasco cruise, time series of fire activity and AOTs are given in Fig. 4. Figure 4a shows the MODIS fire hotspot time series for key regions in the MC for the 2012 burning season. As explained in Reid et al. (2012) to account for satellite orbit, some smoothing of the data are required; in this case a 5-day boxcar is used. Four fire events are visible over the course of the SWM. First, an early-season event in late July/early August is visible in Central Sumatra and Indonesian Kalimantan (predominately western Kalimantan); this is associated with early agricultural burning. A second and much more significant peak in late August is found in Southern Sumatra and Indonesian Kalimantan provinces predominately in the south. This is fairly anomalous behavior, especially for a La Niña year, as this region typically burns very late in the season (Reid et al., 2012).

In September, two more events, one early and one late in the month, are visible. The first, peaking around 7 September is region wide, but is dominated by Sumatra. The last major event, which corresponded with the Vasco cruise, peaked 26 September, with major contributions from southern Sumatra and Kalimantan and more minor contributions from islands to the south of Borneo. As noted in Reid et al. (2012), these peaks in observed fire activity often correspond to dry MJO phases (e.g., 23 August, 26 September) or overall weak MJO activity (e.g., 5 September). The period of 20 July8 August corresponded with a late-phase MJO event. A new MJO event formed on 18 August. We suspect drying ahead of the convective portion of the event perhaps allowed southern Kalimantan to burn more readily on 23 August. The wettest phase of the MJO (phase 3) was in the MC from 28 August to 18 September. A break in precipitation in the southern MC allowed the 8 September fire event, which was dominated by southern Sumatra, and the border of more significant precipitation to the north. It is emphasized, however, that while we believe plots such as Fig. 4 a are indicative of qualitative fire patterns, they are nevertheless influenced by clear sky bias, which also corresponds with MJO activity.

While the MC generally has high background aerosol concentrations from pervasive industrial, shipping and biofuel sources (Reid et al., 2013), peaks in AOTs from AERONET sites largely match fire activity. Fine-mode AOT from four sites are shown in Fig. 4: (b) Singapore; (c) Songkhla (further up the Malay Peninsula in peninsular Thailand), (d) Kuching in Sarawak Malaysia, Borneo, and (e) Notre Dame of Marbel University on Mindanao. Fine mode AOTs from sites near sources typically ranged from 0.1 to 0.3 during background conditions, and 0.4-1.0 during biomass burning events. For the most part, the 23 August event was the largest region 


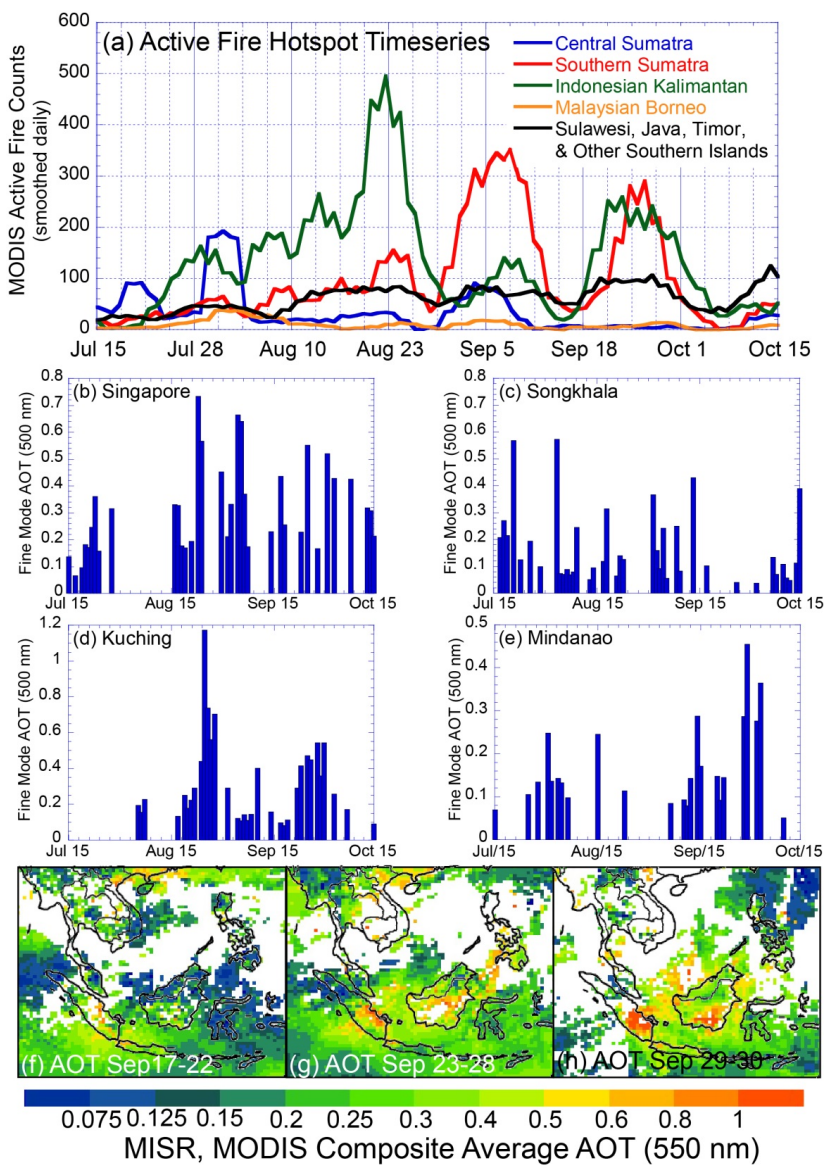

Figure 4. Contextual aerosol data for the 2011 aerosol season. (a) Combined MODIS active fire hotspot prevalence by region. Data is smoothed in a 5-day boxcar filter to help account for orbit. (be). Level 2 AERONET $500 \mathrm{~nm}$ fine mode AOTs for key sites in the Southeast Asian region (marked on Fig. 2b). (f-h) Combined MODIS 7 MISR satellite AOT analysis for the early, mid and late phases of the cruise.

wide, with significant spikes in both Singapore (impacted from Sumatra) and Kuching (impacted largely by southern Kalimantan). The 7 September event is also visible in Singapore, but there is little indication of smoke over Kuching. The Vasco cruise period captured the last AERONET AOT peaks for the season in Singapore, Kuching and in particular Mindanao. This establishes that the ship was well positioned as a long-range receptor for transport from the MC into the SW monsoonal trough.

Because of the generally small fraction of clear sky, frequent high thin clouds, and sometimes extreme AOTs in the region, it is difficult to apply satellite AOT retrievals in a straightforward manner. In particular, sampling bias can be pervasive (Zhang and Reid, 2009). However, the AOT analyses in Fig. 4 that are associated with the meteorological modes presented in Sect. 3.2 are illustrative of regional aerosol loadings: (f) MJO active phase: 17-22 September; (g) MJO transition and TC active phase: 23-27 September; and (h) post TC environment and clearing: 28-30 September. These AOT maps, coupled with the large-scale flow patterns shown in Figs. 2 and 3, are suggestive of a large-scale southwesterly transport event from the MC to the SCS/ES region in the latter half of the cruise. Early in the cruise, while burning was at a minimum, moderate AOTs still existed in the vicinity of Sumatra and Borneo. Air was relatively clean north of the equator. During the development of the TC active phase, the accelerated burning resulted in a 2-3 factor increase in observed AOTs in the source regions. Smoke being transported into the SCS/ES, Celebes Sea, and Sulu Sea is clearly visible. Due to clearing in the post TC phase, retrievals were then possible over much of the region. Heavy smoke is observed as far as $10^{\circ} \mathrm{N}$, with moderate AOTs extending past Luzon. Cleaner air masses with AOT $<0.125$ are clearly visible on the western side of the Philippines. Thus, from the time series in both Figs. 2 and 4, we would expect aerosol concentrations to increase as air masses entered the convective regions of the SCS/ES. As no satellite retrievals were ever made on the track of the Vasco, a question remains as to the aerosol concentrations within the active regions. This is addressed in the next section where we discuss environmental time series from the Vasco.

From an aerosol modeling perspective, Fig. 5 presents a time series of AOT, surface anthropogenic fine-mode concentrations, and biomass burning provided by the NAAPS reanalysis for key transitional days. Through use of AOT data assimilation and satellite precipitation to constrain wet deposition, this is a reliable global model scale perspective of aerosol transport in this data sparse region. Shown are 4 of the days in Fig. 3: 18, 22, 24, and 30 September. By and large, modeled aerosol fields match our expectations from the meteorology. While AOTs are high near source areas in the first half of the cruise, convection over the SCS/ES quickly scavenged aerosol particles near shore. This was particularly true for periods with well-established TC inflow arms. In the second half of the cruise, two strong injection and transport events carried aerosol particles as far north as Luzon. These events were separated by TC Nesat. The relative strengths of anthropogenic pollution vs. biomass burning suggest significant burning enhancement in the last days of the cruise. Of particular note is that in the middle portion of the cruise, model and flow data suggest the northern Palawan region was most dominated by transport up the SCS/ES from the Java Sea and Southeastern Borneo, with the Sulu Sea being dominated by transport from eastern Borneo through the Celebes Sea. This Sulu Sea flow pattern then dominated for the last few days of the cruise, although as discussed in the next section, we suspect some additional industrial sources in the final day.

Finally, aerosol vertical distribution is a crucial element of the system. Unfortunately, CALIPSO was placed in standby mode from 22 to 30 September due to solar flare activity. For the early cruise (17-22 September) thick regional cir- 


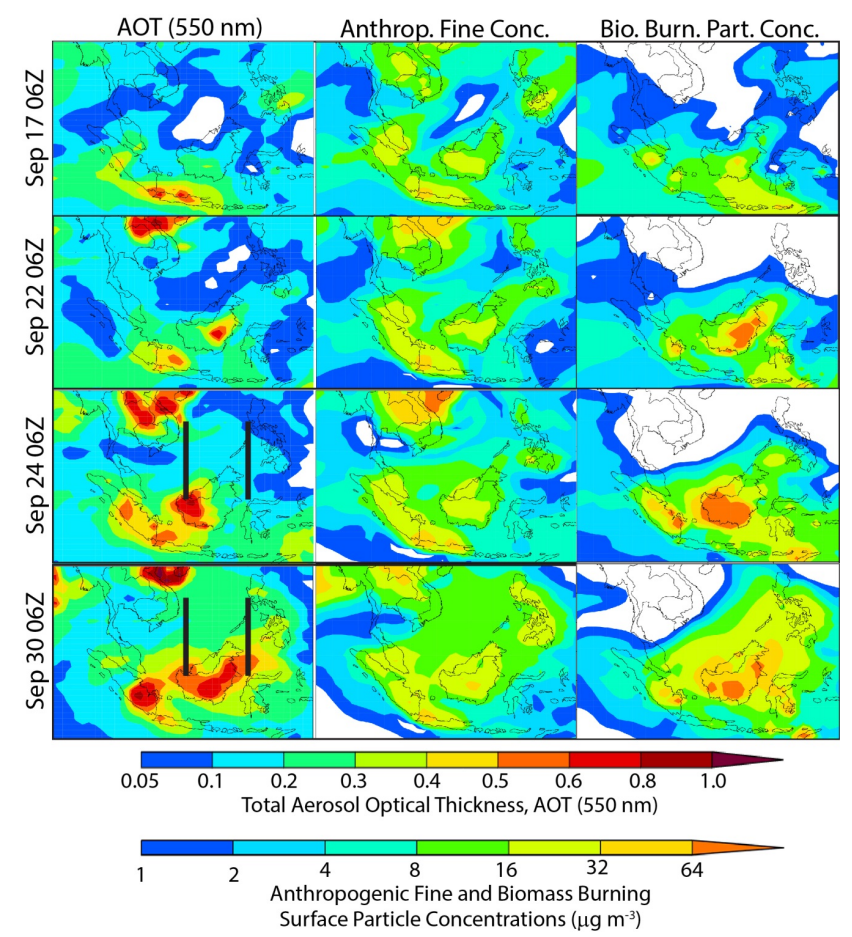

Figure 5. NAAPS $550 \mathrm{~nm}$ aerosol optical thickness (AOT) and surface concentrations for fine mode anthropogenic and biomass burning particle concentrations for 4 key days during the cruise. Satellite data for these 4 days is also presented in Fig. 3. Cross sectional lines for Fig. 6 (24 and 30 September) are placed on the AOT plot.

rus cover and orbital track conspired to prevent meaningful aerosol data collections. However, the NAAPS reanalysis does provide a simulation of aerosol vertical distribution, and we checked for consistency once CALIPSO data was made available for 1 October when cirrus optical thickness was low enough to profile the aerosol layers underneath. These data are presented in Fig. 6. Meridional cross sections for total fine-mode aerosol particle concentration are provided for 24 and 30 September, for 110 and $120^{\circ} \mathrm{E}$ longitude across the SCS/ES and Sulu Sea regions. These meridians are marked on the AOT plots of Fig. 5. At Borneo and immediate outflow regions, NAAPS generally keeps the bulk of the aerosol mass concentration below $3 \mathrm{~km}$, in line with previous remote sensing (Tosca et al., 2011; Campbell et al., 2013) and higher resolution modeling efforts and comparison (Wang et al., 2013). We can interpret this as smoke mixing though a deep planetary boundary layer (PBL), including its cloud entrainment zone. This deep layer progresses well offshore east of Borneo in the Celebes Sea. However, as we go further into the SCS/ES and Sulu Sea, fine-mode aerosol particles concentrations are increasingly predominant in the lowest kilometer.

Cloud-Aerosol LIdar with Orthogonal Polarization (CALIOP) data in Fig. 6, collected on 1 October 2011 (the day after the Vasco returned to port but still probably representative of the second large event), shows the same
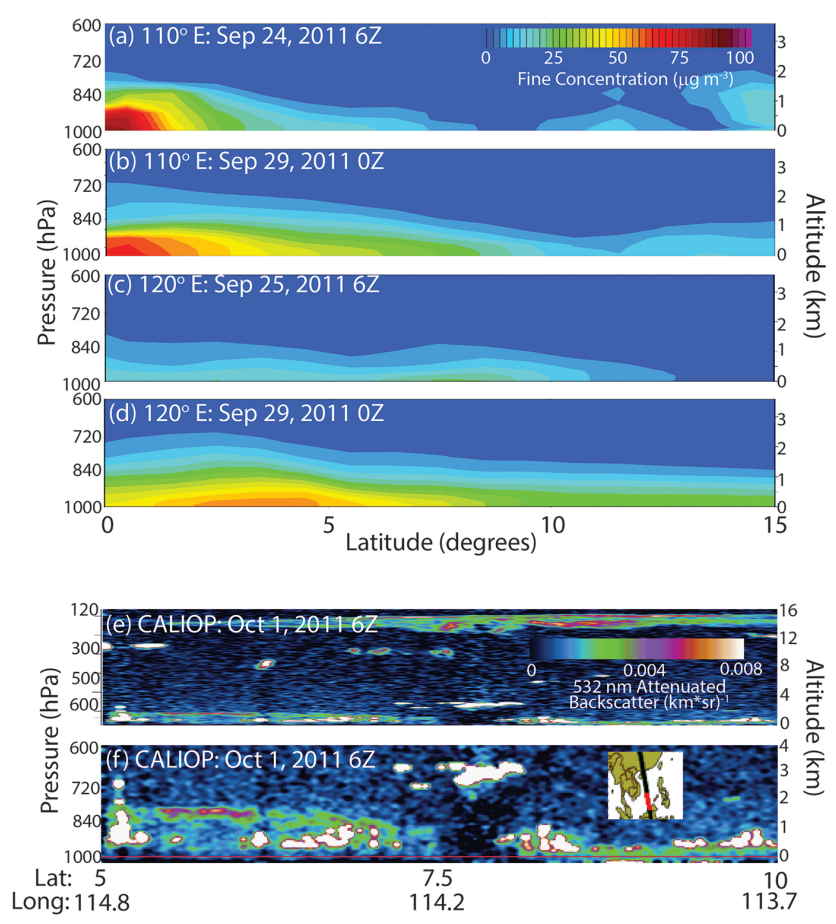

Figure 6. (a-d) Meridional cross sections at 110 and 120 east of NAAPS reanalysis total fine mode aerosol particle concentration for the 25 September $(\mathbf{a}, \mathbf{c})$ and 29 September $(\mathbf{b}, \mathbf{d})$ haze events. (e) CALIOP $532 \mathrm{~nm}$ backscatter across the SCS/ES region on 1 October 2011. (f) Rescaling of (e) for the lowest $4 \mathrm{~km}$. Included is a map of the CALIPSO track.

features, with perhaps an aerosol layer aloft at $1-2 \mathrm{~km}$ in northwestern Borneo, but a sharp aerosol layer below $1 \mathrm{~km}$ across the SCS/ES region. In this case, the scale heights are even lower than NAAPS, perhaps due to numerical diffusion in the vertical in the model. This regional transition from deeper to shallower aerosol scale height, as one moves out in the SCS/ES, is seen very clearly in climatological lidar data (e.g., Campbell et al., 2013). In the context of this cruise, we can explain it as a result of the veering wind shear in the lowest portion of the atmosphere. Aerosol particles in the marine boundary layer (MBL) are transported with a more southwesterly wind. At $850 \mathrm{hPa}$ and above, winds are more westerly. Thus, aerosol particles at higher levels are transported eastward rather than north. Similarly, convective lofting into the lower troposphere will then place the aerosol particles in a westerly wind, and thus any northward component of transport must be associated with the MBL. This finding makes understanding the sea breeze induced ejection of smoke on the western side of Borneo all the more important in the simulation of smoke transport to the Philippines and the monsoonal trough. For eastward transport off of eastern Borneo, the boundary layer and lower free troposphere winds have similar directions. Hence, we find deeper aerosol layers in the Celebes Sea. Based on the 
climatological aspects of wind shear (e.g., Reid et al., 2012), we expect this generally explains the climatological aerosol vertical distribution in the region presented by Campbell et al. (2013). This finding also suggests that the surface sampling by the Vasco was largely indicative of smoke and pollution transport, and is representative.

\section{Results II: Vasco meteorology and aerosol time series}

As Sect. 3 has established the overall nature of the lower troposphere, we can begin to interpret the measurement time series from the Vasco. In particular, we wish to understand how the large-scale conceptual models and observations presented above relate to real world marine boundary layer meteorology and aerosol phenomena. Key meteorological and aerosol measurements, which best depict the overall environment, are presented in Fig. 7. Included are the meteorological parameters: (a) pressure; (b) temperature; (c) wind speed; and (d) precipitation rate. Key aerosol parameters include (e) the $30 \mathrm{~min}$ average water CPC total aerosol concentration; (f) the estimated $\mathrm{PM}_{2.5}$ mass concentrations from filters (corrected to remove sea salt by subtracting sea salt based on $3.26^{*} \mathrm{Na}$ concentration) and organic and black carbon from quartz filters. Also shown are grab-can samples of $\mathrm{CO}$; $(\mathrm{g})$ $\mathrm{PM}_{1}$ ammonium sulfate $\left(\mathrm{NH}_{4}\right)_{2} \mathrm{SO}_{4}$ in red (based on DRUM sampler $\mathrm{S}$ assuming all non-sea salt $\mathrm{S}$ was in $\left.\left(\mathrm{NH}_{4}\right)_{2} \mathrm{SO}_{4}\right)$ with coarse-mode sea salt in blue $(1-10 \mu \mathrm{m}$, based on the $3.26^{*} \mathrm{Na}$ method), and finally (h) NAAPS-derived total finemode particle concentration, differentiated between biomass burning and a combined interactive anthropogenic + biogenic product.

Marked on Fig. 7 are points of interest during the cruise to be discussed herein. They begin with departure from Manila Harbor, followed by our exit from Manila Bay. Our first point of stationary sampling was at Apo Reef, followed the next day at the West Coron site. Long time-period stationary sampling was then conducted at Guntao Island just outside of El Nido, then just outside Malampaya Sound, and then back at Guntao Island again. During the last Guntao Island measurement period, the Vasco experienced the largest cold pool event, a topic of discussion of Sect. 4.2. Late on 26 September, the Vasco took shelter from Typhoon Nesat in Liminangcong harbor, which showed considerable local contamination. Once there was suitable reduction in significant wave heights, the Vasco moved north to just outside El Nido harbor to enable more regional sampling. On the morning of 29 September, the Vasco had to return to Manila harbor via the Mindoro Strait ahead of TC Nalgae. In preparation for Nalgae, our equipment was shut down and boxed up onethird of the way into Manila Bay midday on 30 September.

Based on a preliminary analysis of NAAPS data (e.g., Fig. 5), boundary layer air sources were all coastal Borneo or Southern Sumatra/Java Sea for most of the cruise. The two important exceptions were in the first day and last 2 days

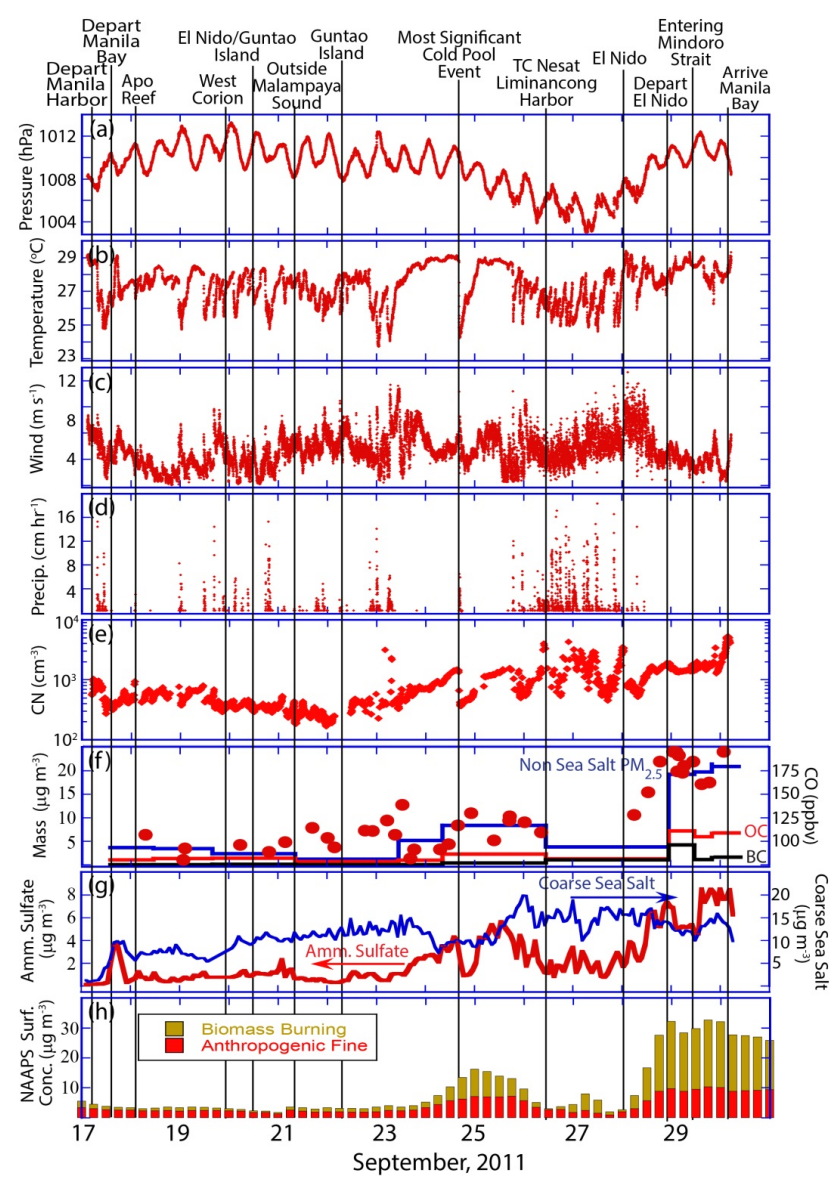

Figure 7. Cruise time series of key meteorological, aerosol and chemistry indicators in $1 \mathrm{~min}$ intervals. Key sampling points and events are marked by vertical lines. (a) Surface pressure (hPa); (b) ambient air temperature $\left({ }^{\circ} \mathrm{C}\right)$; (c) wind speed $\left(\mathrm{m} \mathrm{s}^{-1}\right)$; (d) precipitation rate $\left(\mathrm{cm} \mathrm{h}^{-1}\right)$; (e) CPC total particle count; (f) left axis: $\mathrm{PM}_{2.5}$ gravimetric mass with sea salt subtracted, and associated organic and black carbon; right axis - dots: can carbon monoxide (ppbv); (g) left axis - red: DRUM impactor time series of inferred $\mathrm{PM}_{1}$ inferred ammonium sulfate $\left(\mu \mathrm{g} \mathrm{m}^{-3}\right)$; right axis - blue: inferred coarse mode sea salt $\left(d_{\mathrm{p}}>0.8 \mu \mathrm{m}\right)$. (h) NAAPS total fine mode particle mass segregated into anthropogenic (+biogenic) fine mode and biomass burning.

of the cruise, when model and trajectories suggest some influence from northern Borneo and the Celebes Sea. As discussed above, winds veered with height, with the lower freetropospheric air tracing an origin to the Malay Peninsula and Indian Ocean, where pollution and biomass burning emissions are significantly reduced. Thus, we expect highest particle concentrations to be in the MBL.

\subsection{Daily scale meteorological and aerosol concentration features}

To understand the nature of the coupled meteorologicalaerosol environment we have to reconcile large scale me- 
teorological and remote sensing analyses with the data at a single receptor point (i.e., Vasco). Clearly from Fig. 7, both the meteorology and atmospheric composition observed on the cruise are a convolution of low to high frequency signals. To begin the analysis, we consider features with scale of a day or longer.

As we would expect for a tropical region, overall we see a large measure of consistency in many meteorological features. At daily scales, pressure is relatively constant for the cruise with the exception of a moderate dip $\sim 26-$ 29 September associated with TC Nesat and an embedded diel-solar-tidal signal. Baseline temperatures are also constant at $\sim 28^{\circ} \mathrm{C}$, with a $2{ }^{\circ} \mathrm{C}$ dip also associated with heavy rains from the TC. Surface winds were generally $5-10 \mathrm{~m} \mathrm{~s}^{-1}$ and typically from the Southwest with occasional departure to the north. Precipitation was showery throughout, with precipitation visible in some form most days, but with the most significant events in the outer rain bands associated with TC Nesat. Embedded in these daily scale features are clear highfrequency phenomena; for example, inverse ramp drops in temperature, with associated spikes in wind speed, and often precipitation. As discussed in Sect. 4.2, such high-frequency phenomena are largely associated with convective cells and their associated cold pools.

Within the cruise, we see several large-scale aerosol features. Certainly, just before the Vasco left Manila Harbor and Bay, we observed a high spike in particulate matter, indicative of local pollution. However as the Vasco departed, we entered a cleaner greater-bay regime, upwind of Manila Bay sources. Outside of Manila Bay, a spike in particulate matter was also observed, likely due to local Luzon influence such as from Batangas. "Regional" SCS/ES monitoring was initiated with the Vasco's first anchorage at Apo Reef in Mindoro Strait on September 18. A more typical background period was observed through midday 22 September, followed by a significant aerosol event $\sim 24-26$ September ended by the arrival of TC Nesat. A second even larger event then followed from late 28 September through the return on 30 September.

From the Apo Reef to the northern Palawan anchorages on 23 September, the Vasco was in a very clean aerosol regime. CN counts were generally on the order of $\sim 300-500 \mathrm{~cm}^{-3}$, and non-sea salt $\mathrm{PM}_{2.5}$ was $\sim<2 \mu \mathrm{g} \mathrm{m}^{-3}$. $\mathrm{PM}_{10}$ sea salt was on the order of $5 \mu \mathrm{g} \mathrm{m}^{-3}$. Both fine and coarse particle mass are in line with expectations in a background marine atmosphere (Quinn et al., 1996; Henintzenberg et al., 2000; Reid et al., 2006). On 22 September, particle concentrations reached a mission minimum, with sustained $\mathrm{CN}$ concentrations below $150 \mathrm{~cm}^{-3}$, and non-sea salt $\mathrm{PM}_{2.5}<1 \mu \mathrm{g} \mathrm{m}^{-3}$; at or below our minimum detectable limits. Coarse-mode sea salt remained relatively constant, increasing slightly to $6 \mu \mathrm{g} \mathrm{m}^{-3}$. During this time period, however, we found variable CO grab sample data ranging from $80-118$ ppbv, uncorrelated with particle properties. This first period can be explained through the development of TC Haitang near the SCS/ES, and the formation of a broad southwest to northeast inflow arm on 22 September clearly visible in Fig. 3. As the inflow arm developed, winds accelerated and precipitation from both shallow and deep convective cells increased. Thus, while Borneo/Java Sea air was clearly being transported to the Vasco receptor, precipitation scavenged most fine particles, leaving insoluble trace gases but few particles. Pulses of slightly enhanced CO nevertheless reached the ship. NAAPS correctly captures this period as relatively clean, although total mass concentrations are high by $\sim 2-3 \mu \mathrm{g} \mathrm{m}^{-3}$.

The first observed regional aerosol event having a clear Indonesian or Malay source was initiated on 23 September, when Haitang moved westward, leaving clearer skies and lighter winds. The Vasco remained at the same anchorage outside of El Nido for this entire event. This period saw a slow development in particle concentrations and $\mathrm{CO}$ and was largely precipitation free. Non-sea salt $\mathrm{PM}_{2.5}$ was on average $8-9 \mu \mathrm{g} \mathrm{m}^{-3}$, with black carbon and organic carbon mass fractions on the order of 5 and $20 \%$, respectively. Corresponding CN counts were on the order of $1000-2000 \mathrm{~cm}^{-3}$. This period also corresponded with reduced surface winds across the SCS/ES, and an associated slight reduction in coarsemode sea salt. A significant dip in particle concentrations and temperature was observed late 24 September UTC ( $~ 3$ a.m. local time), which, as we discuss in Sect. 4.2, was associated with a strong trans-SCS/ES convection-cold pool event. Finally, fine particle mass concentrations reached a maximum and then fell precipitously with the arrival of storm conditions associated with TC Nesat. NAAPS identified this event well as a mixture of anthropogenic and biomass burning sources, although total fine-mode mass concentration is overrepresented by $\sim 30 \%$. We suspect this is a result of a low bias in the NOGAPS RH field, which in the context of AOT data assimilation well upstream of the Vasco, results in an overestimation of dry mass relative to ambient scattering.

During the storm period, the Vasco was in safe harbor at Liminangcong; the high and variable $\mathrm{CN}$ are due to local harbor emissions. After TC Nesat passed, the Vasco returned to El Nido for a day of measurements and eventual departure back to Manila. This cruise return period was associated with very light winds and the highest observed particle concentrations, perhaps with a Borneo source. Again, such fair weather is expected on the back side of a strong tropical cyclone such as Nesat, and was further reinforced with the impending arrival of another Category 4 storm, TC Nalgae (Fig. 3, 30 September). Fortunately, the typical southwesterly winds slackened to such an extent that the ships own velocity kept air moving over the bow, thus avoiding selfsampling that would have ruined the return period data set. A time-series analysis of model and trajectory shows that, leading up to this event, transport associated with the last vestiges of the TC Nesat's influence in accelerating regional winds brought the air mass up to the sampling region. Due to wind shear, it is possible it included contributions from both western and eastern Borneo. While we cannot dismiss the possibility of local contamination in the gas can samples 
while we were in safe harbor in Liminangcong, we do see a steady increase in $\mathrm{CO}$ reaching a plateau during the final event.

As the Vasco left El Nido, black and organic carbon mass fractions were on the order of 5 and $40 \%$ suggestive of biomass burning dominance. This period also afforded the only cirrus-free conditions for Microtops sun photometry measurements. $500 \mathrm{~nm}$ AOTs were on the order of 0.30, very similar to the MODIS retrievals shown in Fig. 4h. NAAPS also captured this event well, and yielded a correct 0.3 AOT. However, like the previous event, total particle concentrations are biased high. Again, we suspect this is due to a low bias in the NOGAPS RH fields. Even so, NAAPS suggests a significant enhancement in biomass burning particle concentrations relative to anthropogenic pollution.

Based on back trajectories, NAAPS simulations, and particle concentrations, one would initially be inclined to believe the Vasco sampled one air mass on its return to Manila. However, examination of wind data shows westerly to northerly winds at the very end of the mission. This plus chemistry (Sect. 4.4 and Lagrosas et al., 2015) show that in the last $6 \mathrm{~h}$ of the cruise there are slight perturbations to the sources, perhaps a change in the mixture of biomass burning and industrial pollution or the addition of a regional shipping signal. Indeed, across the horizon on 30 September we saw many high polluting vessels with plumes visible from 10 to $30 \mathrm{~km}$ away.

A final consideration for large scale observations is how aerosol loading covaries with atmospheric soundings, perhaps influencing interpretation of aerosol, cloud and precipitation interaction studies. Figure 8 presents three example cases were we found isolated convection, 18, 25 and 29 September. 18 September was our first stop at Apo Reef, where we observed relatively clean aerosol conditions and isolated convection. Over the $24 \mathrm{~h}$ period we observed many warm rain events with significant precipitation, as shown in Figs. 8a and 7e. For intermediate pollution on 25 September, we encountered significant amounts of boundary layer clouds, but little precipitation (Figs. $8 \mathrm{~b}$ and $7 \mathrm{~d}$ ). On the other end of the spectrum, 29 September was indicative of polluted conditions where there were few boundary layer clouds, but occasional significant convection (Figs. 8c and 7d). Simple correlation studies and current scientific thinking would suggest these cases epitomized aerosol-cloud-precipitation interactions. That is, in clean conditions, we have significant amounts of warm rain. If aerosol particle concentrations are perturbed from background conditions, warm rain ceases, and perhaps there is enhancement in severe cells. However, as demonstrated in Fig. 8d-f, atmospheric soundings were very different for these cases. Being the tropics, one expects relatively consistent potential temperature profiles, which indeed we found to be largely the case (Fig. 8d). But, we can see that for the polluted 25 September case, a clear stronger inversion is present at $700 \mathrm{hPa}$. This inversion corresponds with a lower free-tropospheric dry layer between 900 and
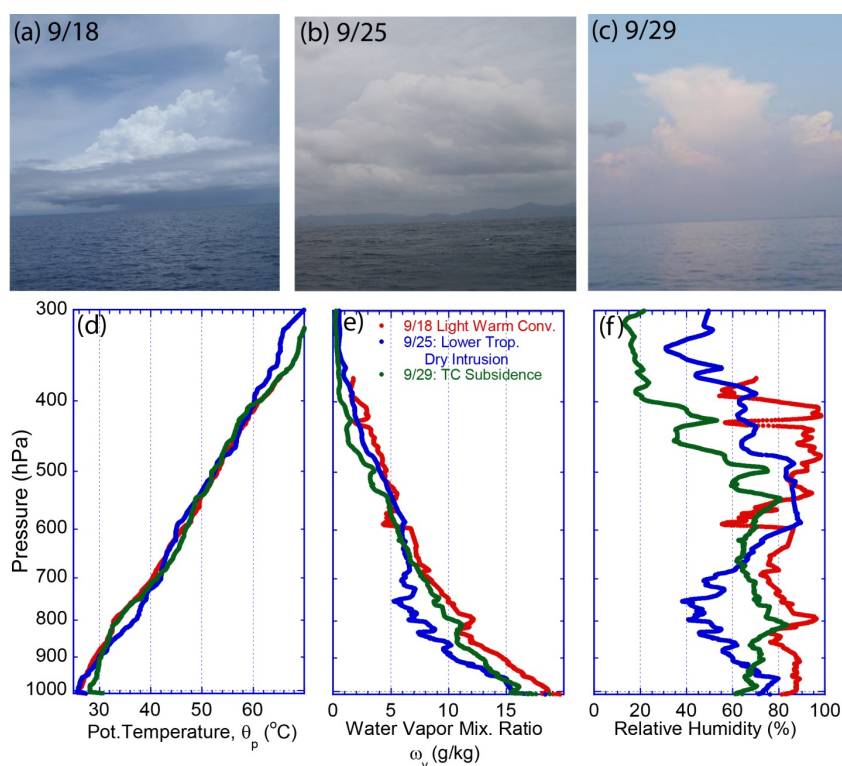

Figure 8. Photographs and corresponding sounding elements for three aerosol regimes during periods of marginal convection. (a) 18 September at Apo reef with isolated warm convection in moderately moist conditions; (b) 25 September at El Nido with warm non precipitating convection with a lower troposphere dry intrusion during the height of the pollution event; (c) 29 September at the northern Sulu Sea with isolated deep convection in overall TC induced subsidence during height of biomass burning event. (d-f) Corresponding Vasco released radiosonde profiles of potential temperature, water vapor mixing ratio, and relative humidity, respectively.

$700 \mathrm{hPa}$ with both halved water vapor mixing ratio (Fig. 8e) and relative humidity (Fig. 8f). This certainly impaired the development of warm rain formation, even without possible aerosol effects. For the most significant biomass burning event (29 September), the PBL was drier than was typical, yet the lower troposphere was relatively moist. But in this case, large TC induced subsidence produced a dry layer in the mid to upper troposphere, strongly capping convection.

To better understand the nature of dry stable layers, Fig. 9a, b present back trajectories initiated at the key "dry altitudes" of $1.6 \mathrm{~km}(850 \mathrm{hPa})$ and $6.8 \mathrm{~km}(500 \mathrm{hPa})$, respectively, for our cases of 18, 25 and 29 September. Tick marks are located every $24 \mathrm{~h}$, and time-height dependencies are provided. For the lower free troposphere, we see clear differences between 18 and 25 and 29 September, with 18 September originating from convection off of Borneo. For both the 25 and 29 September, the lower-to-middle free tropospheric air originated in the Indian Ocean. The NOGAPS timeheight cross section over the Phuket, Thailand radiosonde site clearly shows a dry air intrusion into the region between 2 and $5 \mathrm{~km}(900$ and $600 \mathrm{hPa}$ ). This may be related to subsidence behind the propagating MJO. Nevertheless, it does demonstrate how dynamics in the Indian Ocean and the for- 


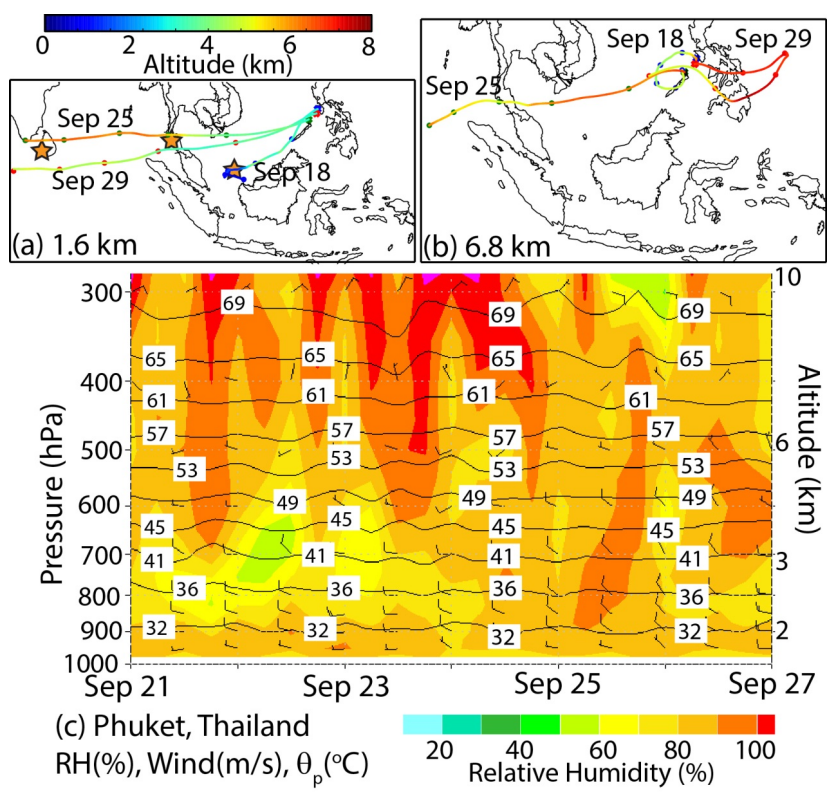

Figure 9. Back trajectories and time height cross sections. (a, b) $1.6 \mathrm{~km}$ and $6.8 \mathrm{~km}$ back trajectories from the Vasco for the cases posted in Fig. 11. (c) Time height cross section for Phuket, Thailand, of relative humidity color $(\mathrm{RH})$ with potential temperature isopleths $\left({ }^{\circ} \mathrm{C}\right)$. Wind barbs are given with full and half bar at 10 and $5 \mathrm{~m} \mathrm{~s}^{-1}$, respectively.

mation of dry layers can be coupled to SCS/ES and Sulu Sea convection and their aerosol environment. In regard to upperlevel subsidence, trajectories are highly divergent, but show significant lifting and subsidence associated with the passage of TCs.

\subsection{High frequency squall line and cold pools phenomenon}

Embedded in the Fig. 7 time series are clear, sharp perturbations in both meteorological and aerosol features. Most significant of these are drops in temperature on the order of $2-5{ }^{\circ} \mathrm{C}$ within minutes, and even here we must consider the response time of the aspirated temperature probe. With the drop in temperature, there was a sharp spike in wind speed, relative humidity (and at times precipitation), as well as a drop in both particle concentration and water vapor mixing ratio. These characteristics are indicative cold pool events related to convective downdrafts (Wakimoto, 1985; Atkins and Wakimoto, 1991; Miller et al., 2008; Zuidema et al., 2012). Over 20 such events are observable in the time series, with significant variability in amplitude. Recovery from the drop in temperature and particle concentration to the pre-event baseline ranged from 1 to $10 \mathrm{~h}$. Some of these events originated from what were clearly local isolated cells. However, investigation of the largest such events suggest that they originate in long-lived squall lines, propagating in the monsoonal flow and initiated from the cold pools of massive thunder-

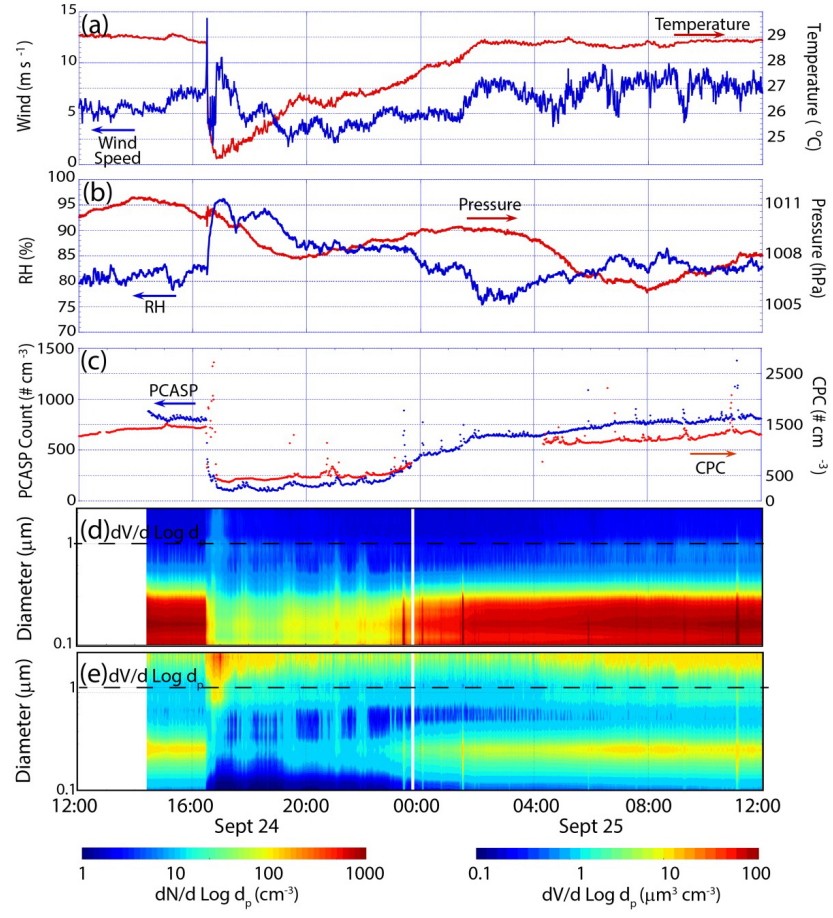

Figure 10. $24 \mathrm{~h}$ times series of meteorology and aerosol parameters centered on the 24 September cold pool event. Tines are in UTC. (a) 1 min temperature and wind speed; (b) 1 min relative humidity and pressure; (c) PCASP and CPC total aerosol particle count; (d) and (e) PCASP number and volume distributions, respectively.

storms over land or along the coast. This phenomenon appears to be extremely important for determining aerosol fate in this region, and deserves detailed study in its own right. For this study, we will limit our discussion to the most significant event observed during the cruise.

The pathology of SCS/ES organized squall line/cold pool phenomena best described by the cruise data was for a 24 September event in the middle of the first significant aerosol transport episode. Key aspects of the 24 September event are presented in Fig. 10 as 1-minute averages. Included are (a) a time series of temperature and wind speed; (b) relative humidity and pressure; (c) PCASP and CPC total particle count; and PCASP (d) number and (e) volume size distributions. The cold pool hit at 16:28 UTC (corresponding to 00:28 LST on 25 September). Wind cup speed accelerated from the background $7-8 \mathrm{~m} \mathrm{~s}^{-1}$ to $14 \mathrm{~m} \mathrm{~s}^{-1}$ within the first $2 \mathrm{~s}$, with flux estimates of gusts at the $2-5$ second level to $25 \mathrm{~m} \mathrm{~s}^{-1}$ within the next $50 \mathrm{~s}$. Winds then momentarily subsided to $5 \mathrm{~m} \mathrm{~s}^{-1}$ for the next $10 \mathrm{~min}$, followed by another increase and decrease over the next hour, and a slow recovery. Corresponding with the wind onset was a $\sim 5^{\circ} \mathrm{C}$ drop in temperature, and increase in relative humidity over the first minutes, although there was only a minor $0.2 \mathrm{hPa}$ perturbation in pressure. Sea surface temperature dropped $0.2^{\circ} \mathrm{C}$ and recovered only after sunrise. Approximately $1 \mathrm{~cm}$ of precip- 
itation occurred over a $1 \mathrm{~h}$ period, which initiated $15 \mathrm{~min}$ after gust front arrival, thus breaking the wind lull. Maximum precipitation rate was on the order of $4 \mathrm{~cm} \mathrm{~h}^{-1}$. Surface particle concentrations dropped precipitously with cold pool arrival: PCASP counts dropping from $\sim 700 \mathrm{~cm}^{-3}$ to $300 \mathrm{~cm}^{-1}$ within $2 \mathrm{~min}$, followed by a further reduction to $150 \mathrm{~cm}^{-1}$ at precipitation onset. CPC dropped from $\sim 1450$ to $400 \mathrm{~cm}^{-1}$. An interesting feature was a clear enhancement in coarsemode sea salt along the gust front. This is, to our knowledge, a first ever report of a maritime corollary to dust producing haboobs (Knippertz et al., 2007; Miller et al., 2008; Seigel and van den Heever, 2012). Particles and meteorological parameters likewise recovered to pre-event levels over the next $10 \mathrm{~h}$.

While the 24 September event was the largest of its kind, it nevertheless demonstrated patterns similar to over 20 other events: a sharp wind increase and temperature and particle decrease is followed by a lull and eventually precipitation from a cell. When these events occurred in association with isolated cells, we often could observe the entire process from cell formation to cold pool onset and, at times, cell propagation over the site. Investigation of the 24 September case, however, led us to a conclusion that despite the short spatial and temporal timescales observed at a receptor site such as the Vasco, they are part of a meteorological phenomenon that spans the entire SCS/ES region. Visible and IR satellite imagery of the SCS/ES region for the $18 \mathrm{~h}$ prior to the 24 September event are presented in Fig. 11. At arrival, the cell was only $30-50 \mathrm{~km}$ along the meridian, with cloud top heights on the order of $12-13 \mathrm{~km}$, well below the $18 \mathrm{~km}$ tropopause height. Tracing the event back in time with 15 min imagery, we found this system, despite its small size, remained organized for nearly $24 \mathrm{~h}$. Imagery suggests that an isolated thunderstorm that formed near the southern tip of Vietnam/Ho Chi Min City initiated a cold pool southward which eventually embedded within the Southwest monsoonal flow. This cold pool triggered an arc cloud formation that triggered a new set of thunderstorms along the arc, which in turn formed a secondary cold pool and repeated.

Squall line features such as observed here have been long noted in the literature (e.g., Trier et al., 1996), although we have been unable to find cases as long-lived as we found during the cruise. There are some similarities in the radar science literature for mid-latitude systems as "bow echoes" (Weisman, 1993). The physics have been studied extensively (e.g., Weisman and Rotunno, 2004), and the importance of vertical wind shear and the presence of mid-tropospheric dry air behind the storm front is well established. However, the nature of the squall lines in the SCS/ES appears to present an extreme case. Figure $11 \mathrm{~g}$ and h show the MODIS Aqua $670 \mathrm{~nm}$ visible and cloud top height products for the 24 September event, $10 \mathrm{~h}$ before it reached the Vasco. Shown is a pair of squall lines, with the southern arc being the one that eventually developed most strongly. We find it interesting that, for the most part, the tops of the clouds making up the squall

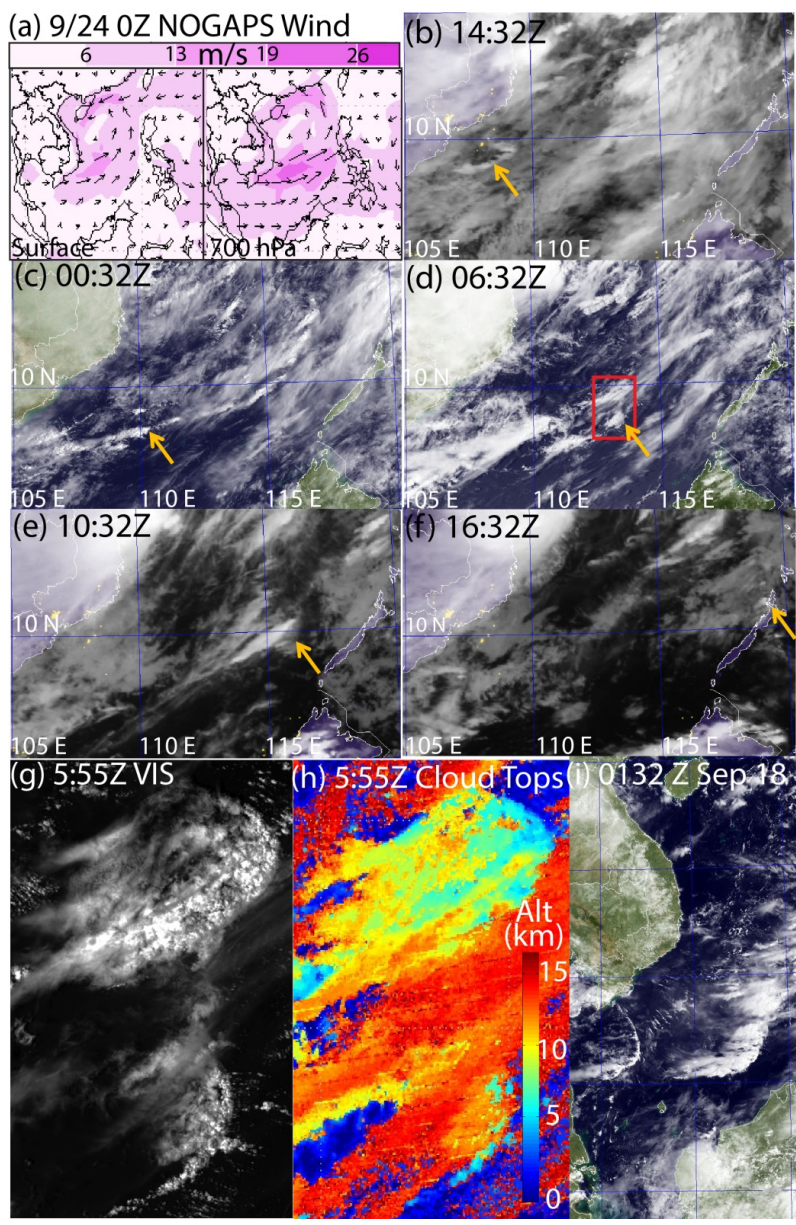

Figure 11. Day visible and night infrared time series of 24 September squall line/cold pool event. (a) 24 September 0Z NOGAPS surface and $700 \mathrm{hPa}$ winds at event initiation. (b) 23 September 14:32 UTC cold pool arc cloud propagating south from Ho Chi Min City initiated thunderstorm. (c) 24 September 00:32 UTC, convective cell spawned by cold pool, propagating to the NNE; (d) 24 September 06:32 UTC cold pool from cell in (c); (e) convective cell spawned by cell in (e); (f) final cell spawned by cold pool from (e) sampled by Vasco; (g, h) $250 \mathrm{~m}$ MODIS Aqua Ch 1 visible and derived cloud height product respectively. Inset in (d) is the domain. (i) 18 September 01:32 UTC MTSAT image of extensive latitudinal dimension of two squall line events.

lines reached only $5-6 \mathrm{~km}$, and hence were most likely icefree. Only isolated cells along the arc became high enough for freezing and further vertical development. However, a review of the satellite loop suggests periodic major storm eruptions along the line, which we surmise help propagate the phenomenon. In comparison, classic mid-latitude bow echoes are very deep along the front; the difference in cloud heights may be related to the relatively larger amounts of CAPE aloft in mid-latitude systems (Takemi, 2014), as well as the location of the capping inversion. Long-lived squall lines are known to develop in environments with finely tuned 
balance between shear and CAPE (Rotunno et al., 1988). The question of whether cold pool propagation is drive by the frequent and relatively shallow convection or the infrequent troposphere-deep convection is one we plan to study in detail in the near future. From an aerosol point of view, the warm versus cold convective components along the line likely have important ramifications for scavenging or redistribution of aerosol particles in the MBL. Similarly, aerosol impacts on warm versus cold convection are likely different. Aerosol particles have even been hypothesized to influence the cold pools themselves (Lebo and Morrison, 2014).

A second important aspect of these cold pools is their extent across the monsoonal flow. The case experienced by the Vasco, while long-lasting, was relatively small in dimension. Frequently, much larger events are observed in our analysis of the satellite data record. An example at the beginning of the research cruise (18 September) is presented in Fig. 11 i. In this case, younger and more developed squall lines are shown, each over $500 \mathrm{~km}$ in length. These events were initiated by major thunderstorms over and just offshore of the Malay Peninsula, with overshooting tops of $>20 \mathrm{~km}$. They propagated across the entirety of the SCS/ES in under $30 \mathrm{~h}$. With such wide ranging extent, they must have swept across the entirety of the SCS/ES, perhaps leaving the very clean condition observed in the northern area. Imagery analysis showed the southern portions of these squall lines developing more strongly on their southern half. This suggests that indeed the veering wind shear is supplying energy from the southern domain.

\subsection{Key aspects of chemistry and particle microphysics}

Detailed analysis of aerosol chemistry, size, and optical properties will be presented in subsequent papers. However, there are key aspects of chemistry and size worth briefly discussing in the context of this regional aerosol source and transport paper. Time series of DRUM sampler derived $\mathrm{PM}_{1}$ for some key elements are presented in Fig. 12: (a) sulfur and potassium and (b) aluminum and vanadium, respectively. Key gas species of $\mathrm{CO}$ and benzene are presented in Fig. 12c as is 2-PenONO 2 (a photo-oxidation product for pentane) and methyl iodide $\left(\mathrm{CH}_{3} \mathrm{I}\right)$ a marker for biomass burning (Akagi et al., 2011). While aerosol source identification in the complex Southeast Asian environment can be very involved (see e.g., Atwood et al., 2013a, b), there are significant features of note. First, though non-sea-salt sulfur can be produced by both industrial and biomass burning (particularly peat burning for sulfur), potassium shows significant enrichment during flaming biomass burning (Reid et al., 2005; Akagi et al., 2011).
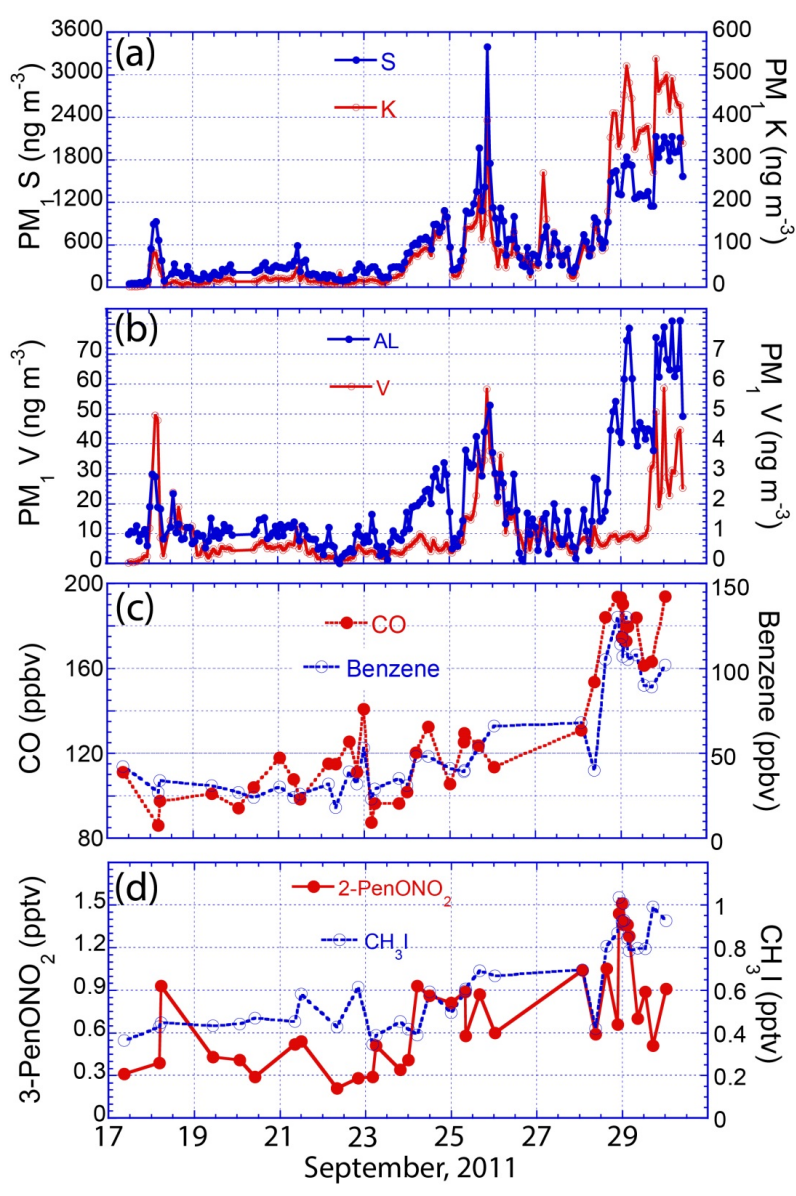

Figure 12. Time series of key elements and gases. (a, b) DRUM time series of sulfur + potassium and aluminum + vanadium, respectively. (c) Carbon monoxide and benzene, both common biomass burning emissions. (d) 2-Pentane oxyl nitrate, a photochemical pentane daughter product and methyl-iodide, a halogenated organic specie also emitted by burning, the oceans, and used in agriculture.

By and large, sulfur and potassium track with each other over the time period, with a significant enrichment in the post-TC Nesat clear area. Aluminum, indicative of regional fine dust, or at times fly ash, also tracks sulfur well and potassium quite well, perhaps indicative of soils entrained in biomass burning plumes. As an indicator of industrial or oil combustion, vanadium shows two significant spikes on 26 and 30 September. This may indicate additional industrial or shipping sources. Based on our trajectory analysis, these cases may very well be influenced from the industrial Singapore-Kuala Lumpur corridor, although high-resolution modeling is required to show this with any certainty. From a gas chemistry point of view, we find that fine aerosol and $\mathrm{CO}$ match reasonably well, with the CO enrichment ahead of the 24-26 September aerosol event perhaps indicative of polluted air masses where particles have been scavenged by precipitation. Benzene, a good and relatively stable in- 
Table 1. Particle size and chemistry characteristics for aerosol environments at the cruises's key sampling locations.

\begin{tabular}{|c|c|c|c|c|c|c|}
\hline Date & Sample location & $\begin{array}{l}\text { Suspected } \\
\text { source }\end{array}$ & $\begin{array}{l}\text { Mode:CMD: } \sigma_{\mathrm{gn}} \\
(\mu \mathrm{m}, \mu \mathrm{m}, \mathrm{n} / \mathrm{a})\end{array}$ & $\begin{array}{l}\text { Mode:VMD: } \sigma_{\mathrm{gv}} \\
(\mu \mathrm{m}, \mu \mathrm{m}, \mathrm{N} / \mathrm{A})\end{array}$ & $\mathrm{BC} \% / \mathrm{OC} \%$ & $\mathrm{~K} / \mathrm{S}$ \\
\hline 16 Sep & Manila Harbor & Metro Manila & & & $12 \% / 19 \%$ & 0.01 \\
\hline 17 Sep & Manila Bay & Local Bay & $0.17: 0.16: 1.73$ & $0.285: 0.30: 1.43$ & & 0.02 \\
\hline 17 Sep & Outside Manila Bay & Sulu Sea/N. Borneo & $0.11 / 0.17: 0.13: 1.37$ & $0.19: 0.21: 1.52$ & $\mathrm{Bdl} / 28 \%$ & 0.08 \\
\hline 23 Sep & Malampaya Sound & Malay Pen. \& Sumatra & $\mathrm{N} / \mathrm{A}$ & $\mathrm{N} / \mathrm{A}$ & $2 \% / 58 \%$ & 0.12 \\
\hline 25 Sep & El Nido & SW Borneo & $0.17: 0.17: 1.61$ & $0.285: 0.27: 1.36$ & $5 \% / 27 \%$ & 0.10 \\
\hline 29 Sep & N. El Nido & Southern Borneo & $0.24: 0.20: 1.54$ & $0.31: 0.29: 1.28$ & $5 \% / 30 \%$ & 0.29 \\
\hline $30 \mathrm{Sep}$ & Outside Manila Bay & $\begin{array}{l}\text { N. Malay Pen. through } \\
\text { Vietnam }\end{array}$ & $0.17: 0.18: 1.56$ & $0.31: 0.28: 1.31$ & $7 \% / 31 \%$ & 0.23 \\
\hline
\end{tabular}

dicator of biomass burning and some industrial emissions, also tracks $\mathrm{CO}$, though with perhaps less enrichment in the last day of the cruise. Methyl iodide tracks with potassium as we would expect from a biomass burning tracer. As 2$\mathrm{PenONO}_{2}$ is a photo oxidation product, its presence demonstrates that these plumes are nominally well aged, particularly for the first event. A reduction in $2-\mathrm{PenONO}_{2}$ for the last day of the cruise with an enhancement vanadium suggests a change in air mass sources and/or aging. At the same time, the ratio of ethyne to excess $\mathrm{CO}$ can also be used as a photochemical clock for plume aging. While relatively noisy from the cruise, it ranged from 15 for the 18 September spike, suggesting a fresh source, was consistently lower (2 to 5) for the 28-30 September event suggested uniformity in fair degree of photochemical aging. Conversely, the 24-26 September event showed more variability (3 to 8), suggesting more mixed photochemical aging and perhaps sources. Such chemistry must be further analyzed with the aid of numerical models.

Regarding aerosol size properties, fine-mode size distributions exhibited some variability throughout the cruise (Fig. 12; Table 1). Number distributions showed relatively strong trends, with cleaner periods having significantly smaller count modal diameters $(\sim 0.11$ to 0.24$)$, though curve fits generally converged to count median diameters in the $0.13-0.17$ range. Implicit in this is variability in geometric standard deviation, which may have significance in regional aerosol-cloud condensation nuclei studies. Also evident in the number distributions is a frequent shoulder on the large side of the distribution, suggesting differences in aerosol physics and chemistry for the number and volume distributions; not uncommon in mixed environments. Volume median diameters were generally in the $0.27-0.29 \mu \mathrm{m}$ range for more polluted events, further exhibiting larger overall size. Actual volume modal diameters are slightly larger $(\sim 0.02)$ than their curve-fit counterparts. These are typical for both regional pollution and biomass burning environments (Reid et al., 2005, 2013), and are comparable to the AERONET derived VMDs (Volume Median Diameter) by Salinas et al. (2013) of $0.26-0.40 \mu \mathrm{m}$ for background and se- vere smoke haze events and the mean value of $0.32 \mu \mathrm{m}$ by Reid et al. (2013) when one considers hygroscopicity.

An interesting aspect of the particle size and chemistry data for high-frequency events is exemplified by the 24 September cold pool case. Selected $30 \mathrm{~min}$ average volume distributions taken from the 1 min time series in Fig. 10e are presented in Fig. 13c. Thirty min average volume distributions leading up to the cold pool event, and $24 \mathrm{~h}$ later are nearly identical. In the $10 \mathrm{~min}$ after arrival, we find a $\sim 80 \%$ reduction in total particle volume, with another factor of 2 reduction following the precipitation event. All this time, VMDs remained fairly stable, although a clear increase in larger particle concentrations is observed post wind burst. Between Fig. 13c and Fig. 10d, e we do not see large changes in particle size, but rather only in amplitude. Similarly, ratios of aerosol chemistry are also fairly similar. We can interpret this data and the $7 \mathrm{~h}$ before initiation of aerosol population recovery as a sweep of clean air aloft and subsequent further rainout of aerosol particles along the cold front. Given the 3-4 $\mathrm{m} \mathrm{s}^{-1}$ marine boundary layer wind speed, over $7 \mathrm{~h}$ we expect a roughly $75 \mathrm{~km}$ zone of marine boundary layer particles being cleaned out by the event upstream of the Vasco. Such a length scale is supported by the satellite images presented in Fig. 11, suggesting a $~ 120-160 \mathrm{~km}$ swath was cut by the event.

\section{Discussion and implications for cloud and precipitation studies}

This paper had three primary objectives: (1) provide a broad overview of the 2011 Vasco cruise, including instruments carried, cruise track, and the general characteristics of the regional environment sampled; (2) relate how aerosol properties co-varied with regional meteorological phenomenon and establish the extent to which biomass burning or industrial pollution from the southern maritime continent can be transported towards or into the boreal summer southwest monsoonal trough; and (3) create a narrative based on field data to help bridge climatological indicators commonly used to assess aerosol life cycle to real world meteorology. To our 

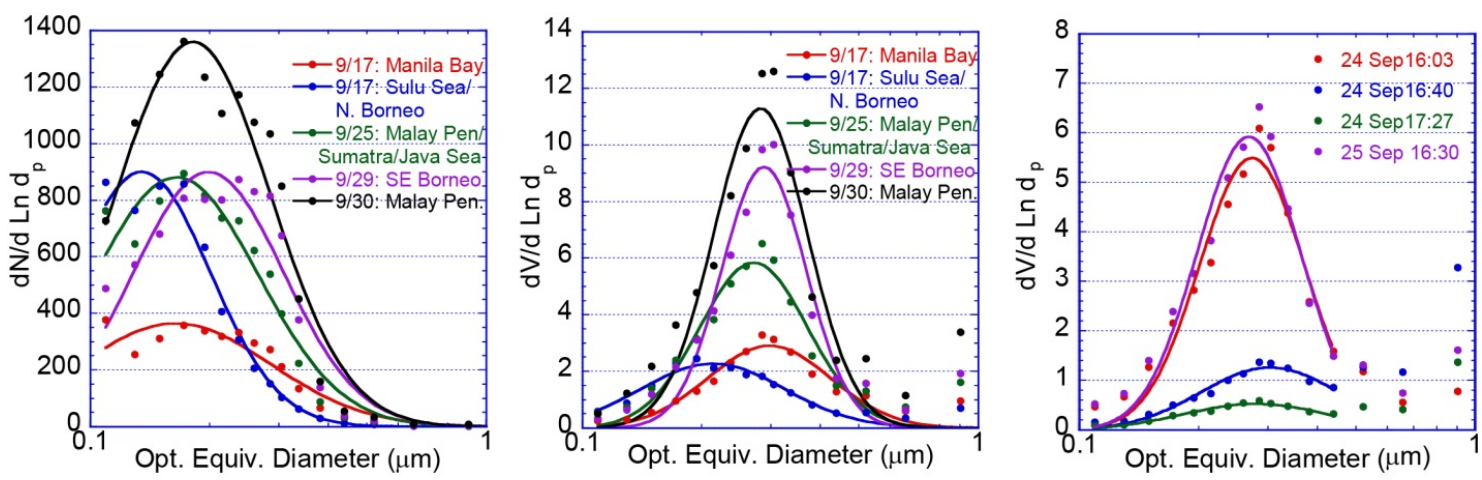

Figure 13. PCASP size distributions for selected regimes. $(\mathbf{a}, \mathbf{b})$ Number and volume distributions for early, middle and late cruise periods. (c) Volume distributions corresponding to the 24 September cold pool event.

knowledge, these are the first published aerosol field measurements in the boreal summertime SCS/ES region.

Central to all meteorological and atmospheric compositional questions for the greater maritime continent is the role of convection. As discussed in Reid et al. (2012, 2013), if ENSO-induced precipitation anomalies influence the overall interannual variability of burning activity, it is the patterns of convection correlated with MJO indices that best describe the specific timing and lifetime of emissions. Indeed, the importance of the MJO to meteorological phenomenon of the MC cannot be understated (Zhang, 2014). Yet we understand very little of the mechanisms of MJO propagation across the region. Embedded in the large scale "forest" point-of-view of ENSO, monsoonal transitions, and the MJO are individual "trees" of specific aerosol and convective events that can be quite diverse in nature, resulting in complex relationships across land, ocean and atmospheric processes.

From the "forest" point of view, the Vasco observed aerosol and meteorology phenomena that largely matched the conceptual model of MC aerosol relationships between fire activity, transport and MJO transport put forth in Reid et al. (2012). The entire 2011 burning season was represented by fire activity slightly elevated with what one expects from a moderately cold ENSO year. Timing of specific burning events was largely consistent with drier phases of the MJO for the western MC (Phases 1 and 5-7). The cruise fortunately took place during an MJO propagation from 3 into 6 , and towards the end of a significant burning event, and so sampled some very clean air as well as the highest AOT recorded in the region for that season (Marbel University Mindanao peaked at $500 \mathrm{~nm}$ AOT of 0.46 , likely as a receptor for southern Kalimantan burning on 28 September).

At the next level of scale, the migration of the MJO into phase 5 around 22 September coincided with the development of regional TCs, as described by Maloney and Hartman (2001). This included the early-cruise development of a TC in the SCS/ES and the pair of late cruise Category 4 TCs propagating westward across Luzon at the very end of the mission. These TCs clearly enhanced convection along a $2500 \mathrm{~km}$ inflow arm spanning the Sumatra/Malay Peninsula to Luzon, and yet also are apparently associated with clear periods and rapid aerosol transport. Indeed, the inflow arm that creates convection, and hence wet deposition, can, at the end of its life cycle, perhaps rapidly carry more polluted air masses into the SCS/ES and Sulu Seas. In these cases, smoke and anthropogenic emissions from Sumatra and Borneo flowed deep into the greater SCS/ES and Sulu Sea regions. It is quite possible that without TC influence, such events would never have been observed. Control for TC activity is a likely necessity in any climatological analysis of regional aerosol transport.

At the finest scales, we were impressed by the nature of coherently propagating squall line systems across the SCS/ES region, and how these perhaps cut large swaths of aerosol particles out of the environment. Even a cursory view of geostationary data in Fig. 11 shows how convection moves along isolated lines embedded in the SCS/ES monsoonal flow. These features are contrary to the more "bubbling pot" concept of tropical convection in large-scale waves. Examining the entire mission data record, we tracked dozens of lines of convection on the order of $100-500 \mathrm{~km}$ in latitudinal length, propagating eastward. Cold pools of storms clearly initiate new convection, which forms another set of cold pools and so on. Veering wind shear allows these storms to cut across aerosol particles transported in the marine boundary layer, effectively removing them from that altitude regime. Perhaps the dry air intrusions in the lower free troposphere from the Indian Ocean provides needed dry air to perpetuate the bow echo-like form observed. But this is speculative at this time and much more research is needed on the physics and conditions that support long squall line phenomenon.

From an aerosol point of view, the prevalence of highresolution features like cold pools, and the warm versus cold convective components along the line, likely have important ramifications for scavenging and/or redistribution of aerosol particles in the MBL. Aerosol particles have even been hypothesized to influence the cold pools themselves (Lebo and Morrison, 2014), offering up a potential feedback. 
While there have been many attempts to correlate convective activity with aerosol indicators, such as AOT, organized squall line behavior such as presented here will defeat such a methodology. In the 24 September case, the high winds of the cold pool were ahead of the precipitating cell. Thus, particle concentrations were dramatically reduced before the cell arrived. In a study of the influence of cold pool generated dust on the parent convective cell, Seigel and van den Heever (2012) found the dust had little effect. Vertical transport of the dust was harmlessly ingested at mid-levels. No doubt, the burst of sea salt produced by the cold pools observed on the cruise would meet a similar fate. But, the findings of Seigel and van den Heever (2012) have perhaps a more interesting corollary. If wind generated aerosol particles do not have a significant effect, do the aerosol particles ahead of the cold pool also have a lesser effect? Are these particles vertically redistributed and eventually entrained into the clouds at mid-levels as well? Finally, what then is the role of vertical wind shear in bringing aerosol particles from the south into the squall line convection? These questions on aerosol life cycle and impacts relate back to the convection physics and the nature of clouds within the squall line. From Fig. $11 \mathrm{~h}$, cloud tops along the squall line are at $6 \mathrm{~km}$ or above, but the efficiency of aerosol scavenging by these features is unknown, although we suspect they are important sinks for regional particles.

The strong relationships between convection patterns, emissions, and transport have serious implications for regional study of aerosol impacts on clouds and precipitation. Even more so, these process implications propagate further into climate change projections. While the studies of Reid et al. (2012) and Xian et al. (2013) provide a good climatological foundation for aerosol life cycle, they are nevertheless a substantial smoothing of highly intricate ejection and convection interactions. However, just because relationships are complex does not imply they are fundamentally chaotic. While future papers will describe in more detail the covariance between aerosol particles and convection, it is appropriate to close this paper recalling the covariance between aerosol populations in the MBL and key features in atmospheric soundings in Fig. 8. Indeed, the presence of substantial amounts of smoke in the boundary layer is fully intertwined with reduced convection and the presence of dry layers aloft, either through large scale subsidence or dry air. At the same time, these dry layers likely influence the gross type and structure of convection irrespective of aerosol particles as CCN. In future studies, we will attempt to constrain aerosol causality components from thermodynamic forcing of regional convection. At the heart of such an endeavor is understanding what controls convective initiation. Clearly, any aerosol-precipitation study has to account for such complex meteorology. Then, when one considers the implications of aerosol-precipitation feedbacks of a changing climate, we must consider how such phenomenon as ENSO, monsoonal transitions, the MJO and TCs will themselves change. For these phenomenon the community is already challenged to perform medium range to seasonal forecasts, let alone develop consistent simulations in climate models. Thus, perhaps the most important lesson of this work is that all aerosol-climate interaction research for the region is predicated on further advancements of fundamental meteorological processes.

\section{Conclusions and hypotheses for future work}

This paper provides a broad overview of the 2-week research cruise of the Vasco for 17-30 September 2011 in the northern Palawan archipelago of the Philippines. The ship was stationed on the windward side of the boreal summertime southwest monsoonal trough, influenced by marine boundary layer (MBL) air originating from the islands surrounding the Java Sea. Lower free tropospheric air above the MBL largely originated in the Indian Ocean, passing through and over the Malay Peninsula. Based on the analysis of Reid et al. (2012), we suspected this region's MBL is impacted by anthropogenic pollution and biomass burning emissions from Indonesia, Malaysia, and Singapore. Given Southeast Asia's ubiquitous cloud cover, it is difficult to determine by remote sensing what the impact is of anthropogenic activities on aerosol populations in a region suspected to be vulnerable to aerosol impacts (Reid et al., 2013). What we do know is largely based on modeling studies, which have difficulty with this most complex of meteorological environments. Hence, this cruise provides the first ever, to our knowledge, contiguous measurements of the South China Sea/East Sea (SCS/ES) and Sulu Sea aerosol environment. Based on this cruise, and a subsequent 1-month September 2012 Vasco cruise to be reported on later, we observed enough of the environment to study aerosol life cycle and pose questions for targeted analysis and testing of cloud impacts. At the very least, the 2011 cruise provides a narrative of real world meteorological phenomena to provide realistic conceptual models of how the regional aerosol life cycle relates to the southwest monsoonal system. In summary, we reported on the following:

1. Boreal summertime 2011 was an El Niño-Southern Oscillation (ENSO) cold "La Niña" phase year, yet had slightly above-average burning activity for this interseasonal state. While peak burning and aerosol optical thicknesses (AOTs) on Sumatra and Borneo for 2011 occurred in mid-August, with $>0.8$ fine mode $500 \mathrm{~nm}$ AOTs recorded by AERONET, the end of the Vasco cruise corresponded to the largest aerosol injection into the Philippines, bringing $500 \mathrm{~nm}$ fine mode AOTs on the order of 0.3 to 0.4 .

2. The Vasco cruise corresponded with Madden-Julian Oscillation (MJO) propagation from phase 2 to 6 , which should enhance burning and transport (Reid et al., 
2012). With MJO propagation came significant tropical cyclone (TC) activity, including the formation of a tropical storm in the SCS/ES in the early part of the cruise (Haitang), and the propagation of two Category 4 storms at the very end (Nesat and Nalgae). This TC activity strongly modulated winds and convection in the greater SCS/ES and Sulu Sea, and thus aerosol regional transport and life cycle.

3. Active convective phases associated with TC development and inflow arms demonstrated extraordinary clean conditions, with condensation particle counter (CPC) concentrations as low as $150 \mathrm{~cm}^{-3}$, although 300 $500 \mathrm{~cm}^{-3}$ were more typical. Corresponding non-sea salt fine-mode particle concentrations in these phases were 1 to $3 \mu \mathrm{g} \mathrm{m}^{-3}$. Coarse sea salt was observed at 4-8 $\mu \mathrm{g} \mathrm{m}^{-3}$. While CALIPSO data during the cruise is unavailable, we suspect that given the regional veering wind shear, highest particle concentrations were in the MBL. This is supported by NAAPS model data, as well as climatological analyses and analysis of CALIOP data from immediately after the cruise period.

4. In between TCs, two significant aerosol injection events were observed, each lasting $\sim 2.5$ days. The first of these increased CPC particle concentrations to $\sim 1000 \mathrm{~cm}^{-3}$, and average non-sea salt fine-mode particle concentrations to $\sim 8 \mu \mathrm{g} \mathrm{m}^{-3}$. We surmise that longrange transport of particles reduction of convection to allow long-range transport for this case was induced by a dry-air intrusion between 800 and $600 \mathrm{hPa}(\sim 2-4 \mathrm{~km})$ from the Indian Ocean. This event is perhaps related to backside MJO subsidence and drying. The aerosol source of this event was likely southwestern Borneo or with some influence of southern Sumatra. A second more significant event, with $\mathrm{CPC}$ counts as high as $5000 \mathrm{~cm}^{-3}$, occurred in the last days of the cruise when an area of very clear sky formed between two Category 4 TCs. In this case, significant upper-level subsidence brought dry air down to below $500 \mathrm{hPa}(6 \mathrm{~km})$. High winds in the final stages of the TC inflow arm leading up to this event may have had a role in its far reaching nature. This air mass was likely dominated by smoke ejection from southern through southeastern Kalimantan/Borneo, and perhaps the Sulu Sea. Veering vertical wind shear resulted in aerosol transport largely in the MBL.

5. While aerosol particle and gas chemistry are subjects of follow-on papers, there are clear biomass burning signals in both events, particularly in regard to $\mathrm{K}+, \mathrm{CO}$, benzene and methyl iodide in the second event. However, in general, air chemistry appears to be a mix of industrial pollution and biomass burning, with sulfur being the most significant element. Black carbon and organic carbon ranged from $2 \%$ for the cleanest peri- ods, 5-7\% for the aerosol events, and up to $12 \%$ in Manila bay. Organic carbon was $\sim 30 \%$, increasing to over $50 \%$ for the cleanest periods.

6. PCASP derived particle size distributions for more polluted cases was typical for a mix of pollution and biomass burning, with volume median diameters on the order of $0.27-0.30 \mu \mathrm{m}$. While the PCASP was inoperable for the cleanest periods, more background conditions in the early part of the cruise showed smaller VMDs, $\sim 0.21 \mu \mathrm{m}$.

7. Frequent rapid decreases in particle concentration and temperature, with corresponding sharp perturbations in winds, were associated with cold pool events. Over 20 such cold pool events were observed during the cruise. We noted, however, that convection in the SCS/ES region is often associated with narrow squall lines propagating in the monsoonal flow. In the most significant case, convection was spawned by a severe thunderstorm over Ho Chi Min City, whose cold pool propagated southward. Once it reached the southwesterly monsoon, another set of convection was spawned, creating its own northeastward propagating event. Over the next $24 \mathrm{~h}$, multiple sets of convection repeated the cycle, leading to arc cloud formations extending $100-200 \mathrm{~km}$ in latitude propagating across the SCS/ES. Upon reaching the Vasco, a 1 min-long high wind event (with up to $25 \mathrm{~m} \mathrm{~s}^{-1}$ instantaneous winds) coincided with a precipitous fall in fine-mode particle concentrations and simultaneous spike in coarse-mode sea salt. Satellite and measured recovery times suggested a $150 \mathrm{~km}$ swath was cut through the marine boundary layer by this event. While cells up to $20 \mathrm{~km}$ high are noted, much of the squall line is made up of nonfreezing clouds with tops of $6 \mathrm{~km}$. Even a cursory view of regional satellite data shows these squall lines occur frequently in the southwest monsoonal flow. While only tens of $\mathrm{km}$ wide, they can extend $500 \mathrm{~km}$ long across the monsoonal flow, likely supported by low-level veering winds. These events likely cut swaths of aerosol particles out of the MBL and thus are likely a major driver of regional aerosol life cycle. The observation of a cold pool well ahead of the convection must be considered in aerosolconvection interaction studies.

Based on the above observations, we discussed implications for aerosol, cloud, and precipitation interaction studies. While aerosol particles are clearly identified by the scientific community as having a critical role in cloud systems, the covariance between the presence of aerosol particles and the atmospheric boundary layer state creates an intertwined chicken and egg problem. The potential for confounding studies is significant. Aerosol injections into the SCS/ES and Sulu Sea regions were clearly modulated by MJO and TC 
phenomenon. Dry layers originating in the Indian Ocean influenced convection thousands of kilometers away. Such features have to be accounted for in any analysis. However, the significant cloud cover in the region makes data assimilation for key variables such as water vapor highly problematic. Aerosol observations also demonstrate substantial clear-sky bias. Higher resolution scales, such as for convection, impart important fine features and process that are not easily replicated in models. Ultimately, this investigation highlights how future studies need tight constraints on the overall meteorology, including high-frequency phenomena such as island ejection of smoke by the sea breeze and cold pools.

Acknowledgements. Organization of this research cruise and associated land base collections required the assistance of a number of organizations, including the staff of the Office of Naval Research-Global program office and reservist unit (esp. J. Johnson, B. McBride, P. Marshall), the Manila Observatory (esp. A. Loyzaga and Fr. D. McNamara), US State Department/ Embassy in Manila (esp. M. T. Villa and D. Saulys), and the Naval Postgraduate School (esp. R. Lind). We are most grateful to the Vasco ship management and crew, managed by Cosmix Underwater Research Ltd, (esp. L. Heymans and A. du Parc). We are also grateful to the host institutions for regional AERONET site deployment and the use of derived optical thickness data herein. Conversations with and guidance from C. Sampson (NRL) on regional tropical cyclone behavior are gratefully acknowledged. Figure construction was also assisted by C. Curtis (NRL) and R. Johnson (UND). Funding for this research cruise and analysis was provided from a number of sources. Vasco time procurement was provided by the NRL 6.1 Base Program via an ONR Global grant to the Manila Observatory. Funding for NRL scientist deployment and instrument analysis was provided by the NRL Base Program and ONR 35. Remote sensing and model analysis was provided by the NASA Interdisciplinary Science Program. Reservist support was provided by ONR Program 38. The AERONET deployments were supported by the NASA Radiation Science Program. Gas chemistry was provided by the NASA Tropospheric Chemistry Program. Author J. R. Campbell acknowledges the support of NASA Interagency Agreement NNG13HH10I on behalf of MPLNET and the SEAC ${ }^{4}$ RS Science Team.

Edited by: W. Birmili

\section{References}

Akagi, S. K., Yokelson, R. J., Wiedinmyer, C., Alvarado, M. J., Reid, J. S., Karl, T., Crounse, J. D., and Wennberg, P. O.: Emission factors for open and d omestic biomass burning for use in atmospheric models, Atmos. Chem. Phys., 11, 4039-4072, doi:10.5194/acp-11-4039-2011, 2011.

Anderson, T. L., Covert, D. S., Marshall, S. F., Laucks, M. L., Charlson, R. J., Waggoner, A. P., Ogren, J. A., Caldow, R., Holm, R. L., Quant, F. R., Sem, G. J., Wiedensohler, A., Ahlquist, N. A., and Bates, T. S.: Performance characteristics of a highsensitivity three wavelength, total, backscatter nephelometer, J. Atmos. Ocean. Tech., 13, 967-986, 1996.
Atkins, N. T. and Wakimoto, R. M.: Wet microburst activity over the southeastern United States: Implications for forecasting, Weather Forecast., 6, 470-482, 1991.

Atwood, S. A., Reid, J. S., Kreidenweis, S. M., Cliff, S. S., Zhao, Y., Lin, N. H., Tsay, S.-C., Chu, Y.-C., and Westphal, D. L.: Size resolved measurements of springtime aerosol particles over the northern South China Sea, Atmos. Environ., 78, 134-143, doi:10.1016/j.atmosenv.2012.11.024, 2013a.

Atwood, S. A., Reid, J. S., Kreidenweis, S. M., Yu, L. E., Salinas, S. V., Chew, B. N., and Balasubramanian, R.: Analysis of source regions for smoke events in Singapore for the 2009 El Niño burning season, Atmos. Environ., 78, 219-230, doi:10.1016/j.atmosenv.2013.04.047, 2013b.

Bond, T. C, Anderson, T. L., and Campbell, D.: Calibration and intercomparison of filter based measurements of visible light absorption by aerosols, Aerosol. Sci. Tech., 30, 582-600, doi:10.1080/027868299304435, 1999.

Cahill, T. A., Goodart, C., Nelson, J. W., Eldred, R. A., Nasstrom, J. S., and Feeny, P. J.: Design and evaluation of the DRUM impactor, in: Proceedings of the International Symposium on Particulate and Multiphase Processes, edited by: Ariman, T. and Veziroglu, T. N., Hemisphere Publishing Corporation, Washington, D. C., 319-325, 1985.

Campbell, J. R., Reid, J. S., Westphal, D. L., Zhang, J., Tackett, J. L., Chew, B. N., Welton, E. J., Shimizu A., and Sugimoto, N.: Characterizing aerosol particle composition and the vertical profile of extinction and linear depolarization over Southeast Asia and the Maritime Continent: the 2007-2009 view from CALIOP., Atmos. Res., 122, 520-543, doi:10.1016/j.atmosres.2012.05.007, 2013.

Chang, C.-P., Wang, Z., Mcbride, J., and Liu, C.-H.: Annual cycle of Southeast Asia-Maritime Continent rainfall and asymmetric monsoon transition, J. Climate, 18, 287-301, 2005.

Chang, C.-P., Ding, Y., Lau, N.-C., Johnson, R. H., Wang, B., and Yasunari T. (Eds.): The Global Monsoon System: Research and Forecast, 2nd Ed., World Scientific Publishers, Singapore, 2011.

Chew, B. N., Campbell, J. R., Reid, J. S., Giles, D. M., Welton, E. J., Salinas, S. V., and Liew, S. C.: Tropical cirrus cloud contamination in sun photometer data, Atmos. Environ., 45, 6724-6731, doi:10.1016/j.atmosenv.2011.08.017, 2011.

Chew, B. N., Campbell, J. R., Salinas, S. V., Chang, C. W., Reid, J. S., Welton, E. J., Holben, B. N., and Liew, S. C.: Aerosol particle vertical distributions and optical properties over Singapore, Atmos. Environ., 79, 599-613, doi:10.1016/j.atmosenv.2013.06.026, 2013.

Chow, J. C., Watson, J. G., Pritchett, L. C., Pierson, W. R., Frazier, C. A., and Purcell, R. G.: The DRI thermal/optical analysis system: Description, evaluation and applications in U.S. air quality studies, Atmos. Environ., 27A, 1185-1201, 1993.

Cinco, T. A., de Guzman, R. G., Hilario, F. D., and Wilson, D, M.: Long-term trends and extremes in observed daily precipitation and near surface air temperature in the Philippines for the period 1951-2010, Atmos. Res., 145-146, 12-26, doi:10.1016/j.atmosres.2014.03.025, 2014.

Clarke, A. D. and Kapustin, V. N.: The Shoreline Environmental Aerosol Study (SEAS): A context for marine aerosol measurements influenced by a coastal environment and long-range transport, J. Atmos. Ocean. Tech., 20, 1351-1361, doi:10.1175/15200426(2003)020<1351:TSEASS>2.0.CO;2, 2003. 
Colman, J. J., Swanson, A. L., Meinardi, S., Sive, B. B., Blake, D. R., and Rowland, F. S.: Description of the analysis of a wide range of volatile compounds in whole air samples collected during PEM-Tropics A and B, Anal. Chem., 73, 3723-3731, 2001.

Cruz, F. T., Narisma, G. T., Villafuerte, M. Q., Chua, K. U., and Olaguera, L. M.: A climatological analysis of the southwest monsoon rainfall in the Philippines, Atmos. Res., 112, 609-616, doi:10.1016/j.atmosres.2012.06.010, 2013.

Draxler, R. R.: HYSPLIT4 users' guide, available at: http:// purl.access.gpo.gov/GPO/LPS47020 (last access: March 2012), 2004.

Draxler, R. R. and Hess, G. D.: Description of the HYSPLIT_4 modeling system. NOAA Tech. Memo. ERL ARL-224, NOAA Air Resources Laboratory, Silver Spring, MD, 24 pp., 1997.

Draxler, R. R. and Hess, G. D.: An overview of the HYSPLIT_4 modeling system of trajectories, dispersion, and deposition, Aust. Meteorol. Mag., 47, 295-308, 1998.

Field, R. D. and Shen, S. S. P.: Predictability of carbon emissions from biomass burning in Indonesia, J. Geophys. Res., 113, G04024, doi:10.1029/2008JG000694, 2008.

Field, R. D., van der Werf, G. R., and Shen, S. S. P.: Human amplification of drought-induced biomass burning in Indonesia since 1960, Nat. Geosci., 2, 185-188, doi:10.1038/NGEO443, 2009.

Hamid, E. Y., Kawasakim, Z.-I., and Mardiana, T.: Impact of the 1998-1998 El Niño event on lighting activity over Indonesia, Geophys. Res. Lett., 28, 147-150, 2001.

Henintzenberg, J., Covert D. C., and Van Dingenen, R.: Size distribution and composition of marine aerosols: a compilation and review, Tellus B, 52, 1104-1122, 2000.

Hogan , T. F. and Rosmond, T. E.: The description of the U.S. Navy Operational Global Atmospheric Prediction System's spectral forecast model, Mon. Wea. Rev., 119, 1786-1815, 1991.

Holben, B. N., Eck, T. F., Slutsker, I., Tanre, D., Buis, J. P., Setzer, A., Vermote, E., Reagan, J. A., Kaufman, Y. J., Nakajima, T., Lavenu, F., Jankowiak, I., and Smirnov, A.: AERONET - A federated instrument network and data archive for aerosol characterization, Remote Sens. Environ., 66, 1-16, 1998.

Hyer, E. J. and Chew, B. N.: Aerosol transport model evaluation of an extreme smoke episode in Southeast Asia, Atmos. Environ., 44, 1422-1427, doi:10.1016/j.atmosenv.2010.01.043, 2010.

Hyer, E. J., Reid, J. S., Prins, E. M., Hoffman, J. P., Schmidt, C. C., Miettinen, J. I., and Giglio, L.: Patterns of fire activity over Indonesia and Malaysia from polar and geostationary satellite observations, J. Atmos. Res., 122, 504-519, doi:10.1016/j.atmosres.2012.06.011, 2013.

IPCC, Parry, M. L., Canziani, O. F., Palutikof, J. P., van der Linden, P. J., and Hanson, C. E. (Eds.): Impacts, Adaptation, and Vulnerability, Climate change 2007, Cambridge University Press, United Kingdom, 2007.

Joyce, R. J., Janowiak, J. E., Arkin, P. A., and Xie, P.: CMORPH: A method that produces global precipitation estimates from passive microwave and infrared data at high spatial and temporal resolution, J. Hydrometeorol., 5, 487-503, 2004.

Kahn, R. A., Nelson, D. L., Garay, M., Levy, R. C., Bull, M. A., Martonchik, J. V., Diner, D. J., Paradise, S. R., Wu, D. L., Hansen, E. G., and Remer, L. A.: MISR Aerosol product attributes, and statistical comparisons with MODIS, IEEE T. Geosci. Remote, 47, 4095-4114, 2009.
Kalnay, E., Kanamitsu, M., Kistler, R., Collins, W., Deaven, D., Gandin, L,. Iredell, M., Saha, S., White, G., Woollen, J., Zhu, Y., Leetmaa, A., and Reynolds, R.: The NCEP/NCAR 40-year reanalysis project, B. Am. Meteorol. Soc., 77, 437-471, doi:10.1175/1520-0477(1996)077<0437:TNYRP>2.0.CO;2, 1996.

Knippertz, P., P., Deutscher, C., Kandler, K., Müller, T., Schulz, O., and Schütz, L.: Dust mobilization due to density currents in the Atlas region: Observations from the Saharan Mineral Dust Experiment 2006 field campaign, J. Geophys. Res., 112, D21109, doi:10.1029/2007JD008774, 2007.

Langner, A. and Siegert, F.: Spatiotemporal fire occurrence in Borneo over a period of 10 years, Global Change Biol., 15, 48-62, doi:10.1111/j.1365-2486.2008.01828.x, 2009.

Lebo, Z. J. and Morrison, H.: Dynamical effects of aerosol perturbations on simulated idealized squall lines, Mon. Wea. Rev., 142, 991-1009, doi:10.1175/MWR-D-13-00156.1, 2014.

Lee, S.-S., Feingold, G., and Chuang, P. Y.: Effect of aerosol on cloud-environment interactions in trade cumulus, J. Atmos. Sci., 69, 3607-3632, doi:10.1175/JAS-D-12-026.1, 2012.

Madden, R. A. and Julian, P. R.: Detection of a 40-50 day oscillation in the zonal wind in the tropical pacific, J. Atmos. Sci., 28, 702-708, 1971.

Mahmud, M.: Mesoscale model simulation of low level equatorial winds over Borneo during the haze episode of September 1997 J. Earth Syst. Sci., 118, 295-307, 2009a.

Mahmud, M.: Mesoscale equatorial wind prediction in Southeast Asia during a haze episode of 2005, Geofizika, 26, 67-84, 2009b.

Maloney, E. D. and Hartman, D. L.: The Madden Julian oscillation, baratropic dynamics, and the North Pacific tropical cyclone formation, part 1: Observations, J. Atmos. Sci., 58, 2545-2558, 2001.

Markowicz, K. M., Flatau, P. J., Kardas, A. E., Remiszewska, J., Stelmaszczyk, K., and Woeste, L.: Ceilometer retrievals of the boundary layer vertical aerosol extinction structure, J. Atmos. Ocean. Tech., 25, 928-944, 2008.

Miettinen, J. and Liew, S. C.: Degradation and development of peatlands in Peninsular Malaysia and in the islands of Sumatra and Borneo since 1990, Land Degrad. Dev., 21, 285-296, doi:10.1002/ldr.976, 2010.

Miettinen, J., Shi, C. H., and Liew, S. C.: Deforestation rates in insular Southeast Asia between 2000 and 2010, Global Change Biol., 17, 2261-2270, doi:10.1111/j.1365-2486.2011.02398.x, 2011.

Miller, S. D., Hawkins, J. D., Kent, J., Turk, F. J., Lee, T. F., Kuchiauskas, A. P., Richardson, K., Wade, R., and Hoffman, C.: NexSat: Previewing NPOESS/VIIRS imagery capabilities, B. Am. Meteorol. Soc., 87, 433-446, doi:10.1175/BAMS-87-4-433, 2006.

Miller, S. D., Kuciauskas, A. P., Liu, M., Ji, Q., J. S. Reid, J. S., Breed, D. W., Walker, A. L., and Al Mandoos A.: Haboob dust storms of the southern Arabian Peninsula, J. Geophys. Res., 113, D01202, doi:10.1029/2007JD008550, 2008.

Moron, V., Robertson, A. W., and Beer, R.: Spatial coherence and seasonal predictability of monsoon onset over Indonesia, J. Climate, 22, 840-850, 2009.

Nichol, J.: Smoke haze in Southeast Asia: A predictable recurrence, Atmos. Environ., 32, 2715-2716, 1998.

O’Neill, N. T., Eck, T. F., Smirnov, A., Holben, B. N., and Thulasiraman, S.: Spectral discrimination of coarse and fine mode optical 
depth, J. Geophys. Res., 108, 4559, doi:10.1029/2002JD002975, 2003.

Parungo, F., Boatman, J. F., Sievering, H., Wilkison, S. W., and Hicks, B. B.: Trends in global marine cloudiness and anthropogenic sulfur, J. Climate, 7, 434-440, 1994.

Quinn, P. K., Kupustin, V. N., Bates, T. S., and Covert, D. S.: Chemical and optical properties of marine boundary layer aerosol particles of the mid-Pacific in relation to sources and meteorological transport, J. Geophys. Res., 101, 6931-6951, 1996.

Reid, J. S., Koppmann, R., Eck, T. F., and Eleuterio, D. P.: A review of biomass burning emissions part II: intensive physical properties of biomass burning particles, Atmos. Chem. Phys., 5, 799825, doi:10.5194/acp-5-799-2005, 2005.

Reid, J. S., Brooks, B., Crahan, K. K., Hegg, D. A., Eck, T. F., O'Neill, N., de Leeuw, G., Reid, E. A., and Anderson K. D.: Reconciliation of coarse mode sea-salt aerosol particle size measurements and parameterizations at a subtropical ocean receptor site, J. Geophys. Res., 111, D02202, doi:10.1029/2005JD006200, 2006.

Reid, J. S., Reid, E. A., Walker, A., Piketh, S., Cliff, S., Al Mandoos, A., Tsay, S. C. and Eck, T. F.: Dynamics of southwest Asian dust particle size characteristics with implications for global dust research, J. Geophy. Res. Atmos., 113, D14212, doi:10.1029/2007JD009752, 2008.

Reid, J. S., Hyer, E. J., Prins, E. M., Westphal, D. L., Zhang, J. L., Wang, J., Christopher, S. A., Curtis, C. A., Schmidt, C. C., Eleuterio, D. P., Richardson, K. A., and Hoffman, J. P.: Global Monitoring and Forecasting of Biomass-Burning Smoke: Description of and Lessons From the Fire Locating and Modeling of Burning Emissions (FLAMBE) Program. IEEE J. Sel. Top. Appl., 2, 144-162, doi:10.1109/JSTARS.2009.2027443, 2009.

Reid, J. S., Xian, P., Hyer, E. J., Flatau, M. K., Ramirez, E. M., Turk, F. J., Sampson, C. R., Zhang, C., Fukada, E. M., and Maloney, E. D.: Multi-scale meteorological conceptual analysis of observed active fire hotspot activity and smoke optical depth in the Maritime Continent, Atmos. Chem. Phys., 12, 2117-2147, doi:10.5194/acp-12-2117-2012, 2012.

Reid, J. S., Hyer, E. J., Johnson, R. S., Holben, B. N., Yokelson, R. J., Zhang, J., Campbell, J. R., Christopher, S. A., L., D. G., Giglio, L., Holz, R. E., Kearney, C., Miettinen, J., Reid, E. A., Turk, F. J., Wang, J., Xian, P., Zhao, G., Balasubramanian, R., Chew, B. N., Janjai, S., Lagrosas, N., Lestari, P., Lin, N. H., Mahmud, M., Nguyen, A., Norris, B., Oanh, N. T. K., Oo, M., Salinas, S. V., Welton, E. J., and Liew, S. C.: Observing and understanding the Southeast Asian aerosol system by remote sensing: An initial review and analysis for the Seven Southeast Asian Studies (7SEAS) program, Atmos. Res., 122, 403-468, doi:10.1016/j.atmosres.2012.06.005, 2013.

Rosenfeld, D.: TRMM observed first direct evidence of smoke from forest fires inhibiting rainfall, Geophys. Res. Lett., 26, 31053108, doi:10.1029/1999GL006066, 1999.

Rotunno, R., Klemp, J. B, and Weisman, M. L.: A theory for strong, long-lived squall lines, J. Atmos. Sci., 45, 463-485, 1988.

Salinas, S. V., Chew, B. N., Mohamad, M., Mahmud, M., and Liew, S. C.: First measurements of aerosol optical depth and Angstrom exponent number from AERONET's Kuching site, Atmos. Environ., 78, 231-241, doi:10.1016/j.atmosenv.2013.02.016, 2013.
Seigel, R. B. and van den Heever, S. C.: Dust lofting and ingestion by supercell storms, J. Atmos. Sci., 69, 1453-1473, doi:10.1175/JAS-D-11-0222.1, 2012.

Smirnov, A., Holben, B. N., Giles, D. M., Slutsker, I., O’Neill, N. T., Eck, T. F., Macke, A., Croot, P., Courcoux, Y., Sakerin, S. M., Smyth, T. J., Zielinski, T., Zibordi, G., Goes, J. I., Harvey, M. J., Quinn, P. K., Nelson, N. B., Radionov, V. F., Duarte, C. M., Losno, R., Sciare, J., Voss, K. J., Kinne, S., Nalli, N. R., Joseph, E., Krishna Moorthy, K., Covert, D. S., Gulev, S. K., Milinevsky, G., Larouche, P., Belanger, S., Horne, E., Chin, M., Remer, L. A., Kahn, R. A., Reid, J. S., Schulz, M., Heald, C. L., Zhang, J., Lapina, K., Kleidman, R. G., Griesfeller, J., Gaitley, B. J., Tan, Q., and Diehl, T. L.: Maritime aerosol network as a component of AERONET - first results and comparison with global aerosol models and satellite retrievals, Atmos. Meas. Tech., 4, 583-597, doi:10.5194/amt-4-583-2011, 2011.

Sorooshian, A., Feingold, G., Lebsock, M. D., Jiang, H., and Stephens, G. L.: On the precipitation susceptibility of clouds to aerosol perturbations, Geophys. Res. Lett., 36, L13803, doi:10.1029/2009GL038993, 2009.

Takemi, T.: Convection and precipitation under various stability and shear conditions: Squall lines in tropical versus midlatitude environment, Atmos. Res., 142, 111-123. doi:10.1016/j.atmosres.2013.07.010, 2014.

Tian, B., Waliser, D. E., Kahn, R. A., Li, Q., Yung, Y. L., Tyranowski, T., Geogdzhayev, I. V., Mishchenko, M. I., Torres, O., and Smirnov, A.: Does the Madden-Julian Oscillation influence aerosol variability?, J. Geophys. Res., 113, D12215, doi:10.1029/2007JD009372, 2008.

Tosca, M. G., Randerson, J. T., Zender, C. S., Nelson, D. L., Diner, D. J., and Logan, J. A.: Dynamics of fire plumes and smoke clouds associated with peat and deforestation fires in Indonesia, J. Geophys. Res., 116, D08207, doi:10.1029/2010JD015148, 2011.

Trier, S. B., Skamarock, W. C., LeMone, M. A., Parsons, D. B., and Jorgensen, D. P.: Structure and evolution of the 22 February 1993 TOGA COARE squall line: Numerical simulations, J. Atmos. Sci., 53, 2861-2886, doi:10.1175/15200469(1996)053<2861:SAEOTF>2.0.CO;2, 1996.

Tsaknakis, G., Papayannis, A., Kokkalis, P., Amiridis, V., Kambezidis, H. D., Mamouri, R. E., Georgoussis, G., and Avdikos, G.: Inter-comparison of lidar and ceilometer retrievals for aerosol and Planetary Boundary Layer profiling over Athens, Greece, Atmos. Meas. Tech., 4, 1261-1273, doi:10.5194/amt-4-1261-2011, 2011.

van der Kaars, S., Tapper, N., and Cook, E. J.: Observed relationships between El-Nino Southern Oscillation, rainfall variaiblity and vegetation and fire history on Halmahera, Maluku, Indonesia, Global Change Biol., 16, 1705-1714, doi:10.1111/j.13652486.2009.02025.x, 2010.

van der Werf, G. R., Randerson, J. T., Collatz, J., Giglio, L., Kasibhatla, P. S., Arellano Jr., A. F., Olsen, S. C., and Kasischke, E. S.: Continental-scale partitioning of fire emissions during the 1997 to 2001 El Niño/La Niña period, Science, 303, 73-76, doi:10.1126/science.1090753, 2004.

Wakimoto, R. M.: Forecasting dry microburst activity over the High Plains, Mon. Weather Rev., 113, 1131-1143, 1985.

Wang, J., Gei, C., Yang, Z., Hyer, E., Reid, J. S., Chew, B. N., and Mahmud, M.: Mesoscale modeling of smoke transport over the 
South Asian maritime continent: vertical distributions and topographic effect, Atmos. Res., 122, 486-503, 2013.

Weisman, M. L.: The genesis of severe, long-lived bow echoes, J. Atmos. Sci., 50, 645-670, doi:10.1175/15200469(1993)050<0645:TGOSLL>2.0.CO;2, 1993.

Weisman, M. L. and Rotunno, R.: A Theory for Strong LongLived Squall Lines Revisited, J. Atmos. Sci., 61, 361-382, doi:10.1175/1520-0469(2004)061<0361:ATFSLS>2.0.CO;2, 2004.

Wheeler M. C., and Hendon, H. H.: An All-Season Real-Time Multivariate MJO Index: Development of an Index for Monitoring and Prediction. Mon. Wea. Rev., 132, 1917-1932, doi:10.1175/1520-0493(2004)132<1917:AARMMI>2.0.CO;2, 2004.

Xian, P., Reid, J. S., Atwood, S. A., Johnson, R., Hyer, E. J., Westphal, D. L., and Sessions, W.: Smoke transport patters over the Maritime Continent, Atmos. Res., 122, 469-485, doi:10.1016/j.atmosres.2012.05.006, 2013

Yuan, T., Remer, L. A., Pickering, K. E., and Yu, H.: Observational evidence of aerosol enhancement of lightning activity and convective invigoration, Geophys. Res. Lett., 38, L04701, doi:10.1029/2010GL046052, 2011.
Yusuf, A. A. and Francisco, H.: Climate change vulnerability mapping for Southeast Asia, Economy and Environment Program for Southeast Asia (EEPSEA) report, available at: http://www. eepsea.net (last access: July 2014), 32 pp., 2009.

Zhang, C.: Madden-Julian Oscillation, Rev. Geophys., 43, RG2003, doi:10.1029/2004RG000158, 2005.

Zhang, C.: Madden-Julian Oscillation: Bridging Weather and Climate, B. Am. Meteorol. Soc., 94, 1849-1870, doi:10.1175/BAMS-D-12-00026.1, 2014.

Zhang J. L. and Reid, J. S.: An analysis of clear sky and contextual biases using an operational over ocean MODIS aerosol product, Geophys. Res. Lett., 36, L15824, doi:10.1029/2009GL038723, 2009.

Zhang, J. L., Reid, J. S., Westphal, D. L., Baker, N. L., and Hyer, E. J.: A system for operational aerosol optical depth data assimilation over global oceans, J. Geophys. Res.-Atmos., 113, D10208, doi:10.1029/2007JD009065, 2008.

Zuidema, P., Li, Z., Hill, R. J., Bariteau, L., Rilling, B., Fairall, C., Brewer, W. A., Albrecht, B., and Hare, J.: On trade wind cumulus cold pools. J. Atmos. Sci., 69, 258-280, doi:10.1175/JAS-D-110143.1, 2012. 